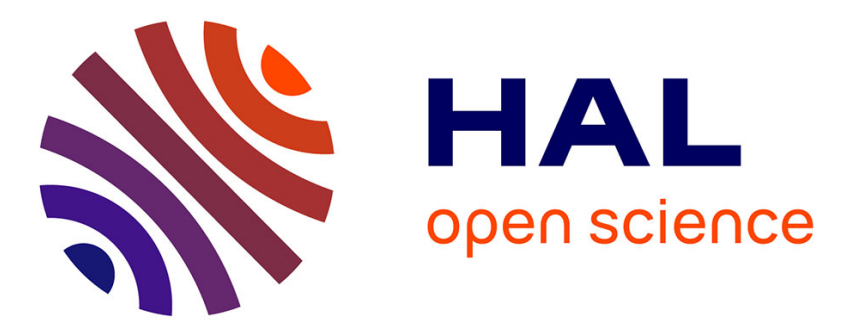

\title{
Limited dispersal and in situ diversification drive the evolutionary history of Rasborinae fishes in Sundaland
}

Arni Sholihah, Erwan Delrieu-trottin, Tedjo Sukmono, Hadi Dahruddin, Juliette Pouzadoux, Marie-ka Tilak, Yuli Fitriana, Jean-françois Agnèse, Fabien L. Condamine, Daisy Wowor, et al.

\section{To cite this version:}

Arni Sholihah, Erwan Delrieu-trottin, Tedjo Sukmono, Hadi Dahruddin, Juliette Pouzadoux, et al.. Limited dispersal and in situ diversification drive the evolutionary history of Rasborinae fishes in Sundaland. Journal of Biogeography, 2021, 48 (9), pp.2153-2173. 10.1111/jbi.14141 . hal-03370830

\author{
HAL Id: hal-03370830 \\ https://hal.science/hal-03370830
}

Submitted on 17 Nov 2021

HAL is a multi-disciplinary open access archive for the deposit and dissemination of scientific research documents, whether they are published or not. The documents may come from teaching and research institutions in France or abroad, or from public or private research centers.
L'archive ouverte pluridisciplinaire HAL, est destinée au dépôt et à la diffusion de documents scientifiques de niveau recherche, publiés ou non, émanant des établissements d'enseignement et de recherche français ou étrangers, des laboratoires publics ou privés. 
1 Research article: Limited dispersal and in situ diversification drive the evolutionary

history of Rasborinae fishes in Sundaland

3

4 Running title: Diversification of Sundaland's Rasborinae

5

6 Arni Sholihah ${ }^{1,2}$, Erwan Delrieu-Trottin ${ }^{1,3}$, Tedjo Sukmono ${ }^{4}$, Hadi Darhuddin ${ }^{5}$, Juliette 7 Pouzadoux ${ }^{1,6}$, Marie-Ka Tilak ${ }^{1}$, Yuli Fitriana ${ }^{5}$, Jean-François Agnèse ${ }^{1}$, Fabien L. 8 Condamine $^{1}$, Daisy Wowor ${ }^{5}$, Lukas Rüber ${ }^{7,8}$, Nicolas Hubert ${ }^{1}$

${ }^{1}$ UMR 5554 ISEM (IRD, UM, CNRS, EPHE), Université de Montpellier, Place Eugène 11 Bataillon, 34095 Montpellier cedex 05, France

12 Institut Teknologi Bandung, School of Life Sciences and Technology, Jalan Ganesha 10, 13 Bandung 40132, Indonesia

$14{ }^{3}$ Museum für Naturkunde, Leibniz-Institut für Evolutions und Biodiversitätsforschung an der 15 Humboldt-Universität zu Berlin, Invalidenstrasse 43, Berlin 10115, Germany

$16{ }^{4}$ Universitas Jambi, Department of Biology, Jalan Lintas Jambi - Muara Bulian Km15, 36122

17 Jambi, Sumatra, Indonesia

$18{ }^{5}$ Division of Zoology, Research Center for Biology, Indonesian Institute of Sciences (LIPI), 19 Jalan Raya Jakarta Bogor Km 46, Cibinong 16911, Indonesia

$20{ }^{6}$ UMR 5244 IHPE (CNRS, IFREMER, UM, UPVD), Université de Montpellier, Place 21 Eugène Bataillon, 34095 Montpellier cedex 05, France

$22 \quad{ }^{7}$ Naturhistorisches Museum Bern, Bernastrasse 15, Bern 3005, Switzerland

$23{ }^{8}$ Aquatic Ecology and Evolution, Institute of Ecology and Evolution, University of Bern, 243012 Bern, Switzerland

26 Correspondence

27 Nicolas Hubert, UMR5554-ISEM, Université de Montpellier, Place Eugène Bataillon, 34095 28 Montpellier cedex 05, France.

29 Email : nicolas.hubert@ird.fr

\section{Funding information:}

32 This study was supported by IRD through annual allocations (2012-2020) and incentive funds 33 (2012-2013), the Ministry of Foreign Affairs and International Development through a BIO34 Asia grant (BIOSHOT 2016-2017) managed by Campus France, the "Institut Français 
35 d'Indonésie" through a "Science et impacts" grant (2016-5758) and the European 36 Commission through a grant from the Southeast Asia - Europe Joint Funding scheme for 37 Research and Innovation program (FRESHBIO, 307943/00). AS benefited from a PhD 38 scholarship from the Indonesian Endowment Fund for Education (LPDP). The Indonesian 39 ministry of research and technology approved this study. 


\section{Abstract}

42 Aim: Sea level changes have long been put forward to explain the colonization of Southeast 43 Asian islands by freshwater aquatic organisms. We examined the relative impact of 44 Sundaland geology since the Oligocene and of Pleistocene Eustatic Fluctuations on the 45 mitochondrial lineage diversification of a species-rich subfamily of freshwater fishes widely 46 distributed in Southeast Asia. We specifically tested if the expansion of exposed lands and 47 increased island connectivity during Pleistocene low sea levels (the Paleoriver hypothesis) 48 induced bursts of diversification.

49 Location: Sundaland

50 Taxon: Rasborinae (Actinopterygii, Cypriniformes, Danionidae)

51 Methods: We aggregated 1,017 cytochrome oxidase I sequences and 79 mitogenomes to 52 delineate Molecular Operational Taxonomic Units (MOTUs) and further reconstruct a time53 calibrated phylogeny of Rasborinae. Ancestral area estimations were conducted using both 54 island and paleoriver partitioning to examine the impact of island connectivity during 55 Pleistocene sea level changes on dispersal. Temporal trends of diversification are explored 56 through statistical selection of best-fit models.

57 Results: The origin of Sundaland mitochondrial lineages is dated at ca. $33 \mathrm{Ma}$ and four major clades are identified, which diversified between ca. 31 and $22 \mathrm{Ma}$. The Island of Borneo and North Sunda paleoriver are identified as the source of Sundaland Rasborinae. Geographical patterns of lineage divergence indicate that most divergence events occurred within islands and diversification under constant birth rate models are the most likely for all clades.

62 Conclusions: The geographical and historical context of diversification of mitochondrial lineages in Rasborinae provides little support for the Paleoriver Hypothesis. The onset of isolation of Borneo from mainland Asia triggered the initial diversification of the group (ca. 31-22 Ma). The late colonization of Java and Sumatra occurred through several independent dispersal events, poorly explained by Pleistocene sea level changes, and frequently followed

67 by in situ diversification.

68

\section{KEYWORDS}

70 Ancestral areas estimation, Cryptic diversity, Dispersal pathways, Diversification models, 71 Historical biogeography, Mitogenomes, Pleistocene climatic fluctuations, Phylogenetic 72 reconstructions, Sea levels. 


\section{INTRODUCTION}

Sundaland has long attracted the attention of evolutionary biologists. From his observations in the $19^{\text {th }}$ century, Alfred Wallace already deduced the biological uniqueness of the "Indo-Malay Islands" compared to neighbouring continental Asia and Celebes (Wallace, 1869). It is now acknowledged that Sundaland's diversity and endemism occur in an area where the geological history is intricate (Hall, 2009, 2013; Lohman et al., 2011). Including the Malay Peninsula and the islands of Borneo, Sumatra, Java and Bali, Sundaland emerged since the Paleocene, ca. 60 million years ago (Ma), until the middle Oligocene ca. $30 \mathrm{Ma}$, as a promontory at the southern end of Eurasia (Fig. 1A). Complex tectonic movements during the Miocene triggered the formation of Borneo between 20 and $10 \mathrm{Ma}$ (Figs. 1B \& 1C) and the subsequent emergence of Sumatra and Java between 10 and $5 \mathrm{Ma}$ (Figs. 1C \& 1D). Insular Sundaland remained partially connected until entering the Pliocene (5.33-2.58 Ma). Upon entering early Quaternary (2.6 Ma), Pleistocene Climatic Fluctuations (PCFs) led to global variations of average temperature (Westerhold et al., 2020; Zachos, Dickens, \& Zeebe, 2008) and sea levels (Miller et al., 2005). Geology and Pleistocene eustasy interacted in Sundaland (Husson, Boucher, Sarr, Sepulchre, \& Cahyarini, 2020; Sarr, Sepulchre, \& Husson, 2019; Sathiamurthy \& Voris, 2006; Voris, 2000; Woodruff, 2010). During Pleistocene glacial periods, sea level dropped between $-60 \mathrm{~m}$ and $-120 \mathrm{~m}$ and created connections between Sundaland's islands (Fig. 1D). These exposed land areas likely had freshwater drainage systems that extended between modern islands, and this is central to the Palaeoriver Hypothesis with respect to fish species dispersal (Kottelat, Whitten, Kartikasari, \& Wirjoatmodjo, 1993; Voris, 2000). Four major paleorivers occurred in Southeast Asia: (1) East Sunda, (2) North Sunda, (3) Malacca straits, and (4) Siam (Fig. 1D). These paleorivers likely impacted the dispersal of Sundaland's freshwater biotas and their evolutionary history (de Bruyn et al., 2013).

A high proportion of Sundaland contemporary freshwater diversity corresponds to cryptic lineages with Pleistocene origins (Dahruddin et al., 2017; de Bruyn et al., 2014; Hubert, Kadarusman, et al., 2015; Hubert et al., 2019; Hutama et al., 2017; Kusuma, Ratmuangkhwang, \& Kumazawa, 2016; Farhana et al., 2018; Sholihah et al., 2021, 2020). Several studies detected congruence between the distribution of some freshwater lineages and the boundaries of paleoriver watersheds (Beck et al., 2017; de Bruyn et al., 2013; Dodson, Colombani, \& Ng, 1995; Tan, Jamsari, \& Siti Azizah, 2012). The timing of speciation across clades during the Pleistocene indicates that PCFs may have triggered bursts of species proliferation in Sundaland through sea level changes (Fig. 2), a mechanism already suggested 
in other areas (Barraclough \& Nee, 2001; Cannon, Morley, \& Bush, 2009; Condamine et al.,

109

110

111

112

113

114

115

116

117

118

119

120

121

122

123

124

125

126

127

128

129

130

131

132

133

134

135

136

137

138

139

140

141 2015; Hubert \& Renno, 2006; Mittelbach et al., 2007; Nores, 1999; Wiens \& Donoghue, 2004). Nevertheless, other factors likely contributed to the build-up of Sundaland diversity, including: (1) pre-Pleistocene geology (Beck et al., 2017; Condamine, Toussaint, et al., 2013; de Bruyn et al., 2014; Dodson et al., 1995); (2) dynamic interactions between insular and paleoriver watershed boundaries (Brown et al., 2013; Esselstyn \& Brown, 2009; Papadopoulou \& Knowles, 2015a, 2015b; Sholihah et al., 2021); (3) varying dispersal abilities as a consequence of life history traits influencing abilities to colonize novel environments, and pass biotic and abiotic filters (Beck et al., 2017; Esselstyn, Timm, \& Brown, 2009; Hubert, Calcagno, Etienne, \& Mouquet, 2015; Logue, Mouquet, Hannes, Hillebrand, et al., 2011; Patel, Weckstein, Patane, Bates, \& Aleixo, 2011; Pouyaud, Sudarto, \& Paradis, 2009); and (4) habitat rearrangements during PCFs (Bird, Taylor, \& Hunt, 2005; Heaney, 1992; Wurster, Rifai, Zhou, Haig, \& Bird, 2019). By contrast to the Last Glacial Maximum (LGM) ca. 17,000 years ago, which housed the maximal extension of paleoriver watersheds, Sundaland is currently considered in a refugial state. This statement underlines the importance to understand the impact of PCFs on diversity patterns in Sundaland for effective conservation efforts. Sundaland is one of the most threatened biodiversity hotspots in Southeast Asia, (Hoffmann et al., 2010; Mittermeier, Turner, Larsen, Brooks, \& Gascon, 2011; Myers, Mittermeier, Mittermeier, da Fonseca, \& Kent, 2000), mostly due to its alarming rate of deforestation during the last decades (Gaveau et al., 2014; Imai, Furukawa, Tsujino, Kitamura, \& Yumoto, 2018; Laumonier et al., 2010), in conjunction with water contamination (Garg, Hamilton, Hochard, Kresch, \& Talbot, 2018) and watershed fragmentation through the development of dams for irrigation and hydroelectric powerplants (Mulligan, van Soesbergen, \& Sáenz, 2020).

Freshwater fishes are tightly dependent of watershed dynamics and constitute model systems to trace historical watershed dynamics (Bernatchez \& Wilson, 1998; de Bruyn et al., 2013; Durand, Persat, \& Bouvet, 1999; Hubert et al., 2007). Sundaland hosts several speciesrich groups that are particularly suited to explore the consequences of PCFs on freshwater diversity patterns (Hubert, Kadarusman, et al., 2015). One of these groups is the Rasborinae (Cypriniformes, Danionidae), a subfamily of iconic and highly diversified, small-size species widely distributed in Sundaland (Brittan, 1972; Dahruddin et al., 2017; Hubert et al., 2019; Kusuma et al., 2016; Liao, Kullander, \& Fang, 2011; Sholihah et al., 2020; Tan \& Armbruster, 2018). Rasborinae comprises eleven genera variously distributed in Asia, of which seven are endemic of Sundaland or much more diverse here than in adjacent areas 
142 (Sholihah et al., 2020). These include Boraras, Brevibora, Kottelatia, Pectenocypris, 143 Rasbora, Trigonopoma and Trigonostigma (Sholihah et al., 2020; Tan \& Armbruster, 2018).

144 The systematics of the subfamily is still confused due to the lack of robust phylogenetic 145 hypothesis of intrarelationships (Brittan, 1972; Hui \& Chian, 2020; Kottelat \& Vidthayanon, 146 1993; Kottelat \& Witte, 1999; Liao, Kullander, \& Fang, 2010; Liao et al., 2011). However, 147 the monophyly of Rasborinae is supported by both molecular and morphological characters 148 (Saitoh et al., 2006; Stout, Tan, Lemmon, Lemmon, \& Armbruster, 2016; M. Tan \& 149 Armbruster, 2018; K. L. Tang et al., 2010). Rasborinae encompasses ca. 80 species in 150 Sundaland (Sholihah et al., 2020), representing ca. 75\% of Rasborinae diversity (Eschmeyer, 151 Fricke, \& van der Laan, 2018; Froese \& Pauly, 2020). Recent genetic reappraisals of 152 Rasborinae species diversity in Sundaland confirmed species boundaries and distribution 153 ranges, along with the recognition of a substantial amount of cryptic diversity (Dahruddin et 154 al., 2017; Hubert et al., 2019; Sholihah et al., 2020). Most cryptic lineages identified have 155 very narrow, non-overlapping distribution ranges, suggesting landscape fragmentation mostly 156 157 contributed to generate this diversity (Sholihah et al., 2020). However, the origin and underlying evolutionary dynamics of this diversity remain largely unexplored. In particular, 158 the historical connectivity between Sundaland and the continent during the isolation of 159 Borneo (ca. 20-30 Ma), and the subsequent emergence of Sumatra (ca. 20-10 Ma) and Java 160 (ca. 10-5 Ma), questions the dynamics of colonization of Sundaland by Rasborinae. Several 161 potential scenarios can be predicted, ranging from an origin through in situ lineage 162 proliferation initiated in Borneo after its isolation (ca. 20-30 Ma) to multiple immigrations 163 164 events from the continent during the emergence of Sundaland islands (ca. 30-5 Ma) (Sholihah et al., 2021; Šlechtová, Musilova, Tan, Kottelat, \& Bohlen, 2021).

Here, we explore the phylogenetic relationships of Sundaland's Rasborinae through 166 mitochondrial genome skimming (Dodsworth, 2015; Straub et al., 2012), with the aim to 167 examine the potential impacts of Sundaland geology and Pleistocene sea level changes on 168 mitochondrial lineage proliferation of this species-rich group. We addressed the following questions: (1) Did Rasborinae diversify (a) through in situ radiation in Sundaland (i.e. monophyly of Sundaland Rasborinae) once Borneo isolated from Mainland (ca. 30-20 Ma) or (b) through multiple colonization events from Mainland followed by in situ diversification

172 (i.e. polyphyly of Sundaland lineages) during the emergence of Sundaland (ca. 30-5 Ma)? (2)

173 Did paleorivers serve as dispersal pathways between islands during Pleistocene low sea levels and enabling the colonization of Sundaland islands? (3) Did paleoriver watersheds prompt allopatric divergence across their boundaries? (4) Did PCF affect rates of mitochondrial 
lineage diversification? Through a dense taxonomic, spatial and mitochondrial genomic sampling, Rasborinae phylogenetic intrarelationships were inferred and mitochondrial divergence events dated to explore dynamics of lineage proliferation through ancestral area estimations and statistical selection of best-fit diversification models.

\section{MATERIALS AND METHODS}

\subsection{Analytical procedure and sampling}

The species diversity of the subfamily Rasborinae has been recently revisited in Sundaland through standardized mitochondrial DNA-based approaches (Dahruddin et al., 2017; Hubert et al., 2019; Sholihah et al., 2020). Here, the objective is to take advantage of this updated cytochrome oxidase I (i.e. DNA barcode) reference library to explore the Rasborinae intrarelationships and guide taxon sampling for further mitogenome skimming (Dodsworth, 2015; Straub et al., 2012). As the earliest branching events and intrarelationships are still unknown in Rasborinae (Brittan, 1972; Liao et al., 2010), mitogenomes were first used to reconstruct a backbone phylogeny and identify major clades. Then, mitogenomes were combined to all DNA barcodes available to reconstruct phylogenetic relationships within each clade based on a dense taxon sampling. Sampling and collection management is as described in Sholihah et al. (2020). Specimens were captured using gears such as electrofishing, seine nets, cast nets and gill nets across sites that encompass the diversity of freshwater lentic and lotic habitats in Sundaland (Fig. 1). Specimens were identified following original descriptions where available, as well as monographs (Kottelat, 2013; Kottelat et al., 1993) and further validated through DNA barcodes by including records from type localities (Hubert et al., 2019; Sholihah et al., 2020). Species names were further validated using several online catalogues (Eschmeyer et al., 2018; Froese \& Pauly, 2020). Specimens were photographed, individually labelled, and voucher specimens were preserved in a 5\% formalin solution. Prior to fixation a fin clip or a muscle biopsy was taken and fixed separately in a $96 \%$ ethanol solution for further genetic analyses. Both tissues and voucher specimens were deposited in the national collections at the Museum Zoologicum Bogoriense (MZB), Research Center for Biology (RCB), and Indonesian Institute of Sciences (LIPI).

\subsection{Mitogenomes skimming}

Genomic DNA was extracted using a MINIPREP SIGMA extraction kit following manufacturer's specifications. A 651-bp segment from the 5' region of the cytochrome oxidase I gene (COI) was amplified as described in Sholihah et al. (2020). PCR 
210 amplifications were done using the primers cocktails C_FishF1t1/C_FishR1t1 including M13 211 tails (Ivanova, Zemlak, Hanner, \& Hébert, 2007) in a final volume of $10.0 \mu$ l containing $5.0 \mu 1$ 212 Buffer $2 \mathrm{X}, 3.3 \mu \mathrm{l}$ ultrapure water, $1.0 \mu \mathrm{l}$ each primer $(10 \mu \mathrm{M}), 0.2 \mu \mathrm{l}$ enzyme Phire Hot Start II 213 DNA polymerase (5U) and $0.5 \mu 1$ of DNA template ( $\sim 50 \mathrm{ng})$. Amplifications were conducted 214 as followed: initial denaturation at $98^{\circ} \mathrm{C}$ for $5 \mathrm{~min}$ followed by 30 cycles denaturation at $98^{\circ} \mathrm{C}$ 215 for $5 \mathrm{~s}$, annealing at $56^{\circ} \mathrm{C}$ for $20 \mathrm{~s}$ and extension at $72^{\circ} \mathrm{C}$ for $30 \mathrm{~s}$, followed by a final extension 216 step at $72^{\circ} \mathrm{C}$ for $5 \mathrm{~min}$. The PCR products were purified with ExoSap-IT (USB Corporation, 217 Cleveland, OH, USA) and sequenced in both directions. The sequences and collateral 218 information are available in BOLD (Ratnasingham \& Hebert, 2007) in the data set DS219 BIFRA (Table S1, dx.doi.org/10.5883/DS-BIFRA).

220 Genomic libraries for mitogenome skimming were prepared following the protocol 221 developed by Tilak et al. (2015) for multiplexed Illumina sequencing. Genomic DNA was 222 physically fragmented through ultrasound $(35 \mathrm{kHz})$ for a duration varying between 10 and 20 223 min using an ultrasonic cleaning unit (Elmasonic One). We followed the Illumina library 224 preparation procedure with blunt-end repair, adapter ligation, adapter fill-in and indexing 225 PCR steps (13 cycles) developed by Meyer and Kircher (Meyer \& Kircher, 2010). Each step was followed by a purification using SPRI bead suspensions (Agencourt ${ }^{\circledR}$ AMpure ${ }^{\circledR}$ XP), adding 1.7 volume of Agencourt ${ }^{\circledR}$ AMpure ${ }^{\circledR}$ XP reagent per volume of sample and eluted in $25 \mu 1$ of ultra-pure water. Quantification of DNA libraries was done with a Nanodrop ND-800 spectrophotometer (Nanodrop technologies). Indexed libraries were pooled using their relative concentrations to ensure equimolarity and a single pool was single-read sequenced (150 bp long reads) on Illumina HiSeq 2500 at MGX (Montpellier, France). Mitogenomes were then assembled on Unipro UGENE (Okonechnikov et al., 2012) by reference to the closest mitogenome available among the 10 Rasborinae mitogenomes available in GenBank. Complete mitogenomes were then annotated using the online tool MitoAnnotator (Iwasaki et al., 2013) available at mitofish.aori.u-tokyo.ac.jp. Annotated mitogenomes are accessible in GenBank (Table S1). estimated at $43 \mathrm{Ma}$ (Betancur-R et al., 2017). Thus, tRNAs and control region were trimmed for phylogenetic reconstructions due to their fast substitution rates, and likely high levels of homoplasy. Protein and ribosomal RNA (rRNA) coding regions were retained and 
individually partitioned in subsequent phylogenetic reconstructions. First, a maximum

244 likelihood (ML) tree was reconstructed using a partitioned model for each protein and rRNA coding regions with a GTR $+\mathrm{I}+\Gamma$ model as implemented in RAxML-HPC Blackbox (Miller,

246 Pfeiffer, \& Schwartz, 2010) with RAxML 8 (Stamatakis, 2014). Topological support was

247 estimated with 5,000 non-parametric bootstrap replicates. Second, a calibrated tree was 248 reconstructed using Bayesian inferences as implemented in BEAST 2.6.2 (Bouckaert et al., 249 2014; Heled \& Drummond, 2010). The most likely substitution models were jointly 250 determined for all partitions using ModelFinder (Kalyaanamoorthy, Minh, Wong, von 251 Haeseler, \& Jermiin, 2017) as implemented in the IQTREE online webserver (Nguyen, 252 Schmidt, Von Haeseler, \& Minh, 2015) at http://iqtree.cibiv.univie.ac.at. The selected models 253 were further used to conduct a Bayesian partitioned analysis based on a Yule model (uniform 254 birth rate), relaxed clock with log normal distribution, and standardized site models as 255 implemented in the SSM package in BEAST 2.6.2. Two Monte Carlo Markov Chains 256 (MCMC) of 50 million generations (burnin of 10\%) were conducted to check for convergence and to check that ESS estimates reached 200 using Tracer 1.7.1 (Drummond, Suchard, Xie, \& Rambault, 2012). Two clock rates were jointly estimated for rRNA and protein-coding regions along tree topology. MCMCs were initiated with a $0.3 \%$ of divergence per million years (Myrs) for rRNA (Hardman \& Lundberg, 2006; Orti, 1997) and 1.2\% per Myrs for protein-coding regions (Bermingham, McCafferty, \& Martin, 1997). The two runs were then combined with LogCombiner 2.6.2 (Bouckaert et al., 2014) and the maximum clade credibility tree, median age estimates and corresponding $95 \%$ highest posterior density (HPD) were summarized using TreeAnnotator 2.6.2 (Bouckaert et al., 2014). This analysis was repeated with a birth-death model of diversification to assess the potential influence of the branching process prior on divergence time estimates (Ritchie, Lo, \& Ho, 2017). Both ML and Bayesian inferences were rooted using an assortment of mitogenomes (Table S1) available for several closely related subfamilies of Danionidae as well as other Cypriniformes families following previously published phylogenetic hypotheses (Betancur-R et al., 2017; Chang, Rabosky, Smith, \& Alfaro, 2019; Rabosky et al., 2018; K. L. Tang et al., 2010).

2.4 DNA barcodes, mitochondrial lineage delimitation and clade-specific phylogenetic inferences

Once major clades were identified within the subfamily, all DNA barcodes available 275 from previous studies were compiled (Table S1). DNA barcode sequences were selected according to a preliminary screening of their phylogenetic affinities and robustness of the 
phylogenetic inferences. A Neighbour Joining (NJ) was first reconstructed for the 1,097 DNA barcodes from Sholihah et al. (2020) and branching support was estimated through 5,000 bootstrap replicates using PAUP 4.0a (Swofford, 2001). Only DNA barcode records related to species with mitogenomes available, with bootstrap proportions (BP) above $80 \%$ were retained. Genetic delimitation of species follows the protocol described in Sholihah et al. (2020). Four different sequence-based methods of species delimitation were used to delimitate Molecular Operational Taxonomic Units (MOTUs) (Blaxter et al., 2005) using the 1,097 DNA barcodes dataset. These methods were: (1) Refined Single Linkage (RESL) as implemented in BOLD and used to generate Barcode Index Numbers (BIN) (Sujeevan Ratnasingham \& Hebert, 2013), (2) Automatic Barcode Gap Discovery (ABGD) (Puillandre, Lambert, Brouillet, \& Achaz, 2012), (3) Poisson Tree Process (PTP) in its multiple rates version (mPTP) as implemented in the stand-alone software mptp_0.2.3 (Zhang, Kapli, Pavlidis, \& Stamatakis, 2013), and (4) General Mixed Yule-Coalescent (GMYC) in its multiple rate version (mGMYC) as implemented in the R package 'Splits' 1.0-19 (Fujiwasa \& Barraclough, 2013). RESL and ABGD used DNA alignments as input files, while a ML tree was used for mPTP and a Bayesian Chronogram based on a strict-clock model using a $1.2 \%$ of genetic distance per Myrs for mGMYC. The ML tree for mPTP was reconstructed using RAxML 8 using a GTR $+\Gamma$ substitution model (Stamatakis, 2014) and the ultrametric and fully resolved tree for mGMYC was reconstructed using BEAST 2.6.2 with two independent Markov chains of 50 million generations each including a Yule pure birth model tree prior, a strict-clock model and a GTR $+\mathrm{I}+\Gamma$ substitution model. Both runs were combined using LogCombiner 2.6.2 and the maximum clade credibility tree was constructed using TreeAnnotator 2.6.2. Duplicated haplotypes were pruned for further species delimitation analyses.

Once DNA barcodes were selected and MOTUs delimited, DNA barcode and 302 mitogenome alignments were concatenated for each of the major clades identified. Phylogenetic relationships within clades were reconstructed using the Bayesian analysis implemented in the StarBEAST2 package (Ogilvie, Bouckaert, \& Drummond, 2017) from the BEAST 2.6.2 suite (Bouckaert et al., 2014). This approach implements a mixed-model including a coalescent component within MOTU and a diversification component between MOTU that allows accounting for variations of substitution rates within and between MOTUs (Ho \& Larson, 2006; Ritchie et al., 2017). StarBEAST2 jointly reconstruct and optimize gene trees and MOTU trees, and as such requires the designation of MOTUs, which were determined using the majority rule consensus of the lineage delimitation analyses. After 
311 preliminary analyses, phylogenetic reconstructions were conducted using a single partition 312 including rRNA and protein-coding regions, GTR $+\mathrm{I}+\Gamma$ substitution model, uncorrelated log313 normal species tree model (UCLN), and MCMCs of 60 million generations. Age of each 314 clade MRCA estimated from the backbone phylogeny was used as a calibration point with a 315 normal distribution and a sigma of 1.0. Clock rate was estimated and an initial value of $0.8 \%$ 316 of divergence per Myrs was used according to the initial BEAST 2.6.2 analysis of the 317 mitogenome dataset. Independent runs were combined using LogCombiner 2.6.2 (Bouckaert 318 et al., 2014). Gene and MOTU maximum clade credibility trees, median age estimates and 319 corresponding 95\% HPD were summarized using TreeAnnotator 2.6.2 (Bouckaert et al., 320 2014). All phylogenetic reconstructions were performed using CIPRES (Miller et al., 2010), 321 and phylogenetic trees and alignments have been deposited in Dryad 322 (doi.org/10.5061/dryad.tb2rbp00g).

\subsection{Diversification rates estimation}

Lineages through time (LTT) were plotted using the MOTU trees of each major 326 clades with the R-package 'ape' (Paradis \& Schliep, 2019). Confidence intervals were computed using 1,000 dated trees sampled along the StarBEAST2 MCMC. To test the impact of past environmental dynamics on diversification, we relied on a ML framework with five diversification models (constant-rate, time-dependent, temperature-dependent, sea-leveldependent, and diversity-dependent models) and their variants (Condamine, Rolland, \& Morlon, 2019, 2013). In total, we fitted 17 diversification models (Table S2) using the Rpackages 'RPANDA' 1.3 (Morlon et al., 2016) and 'DDD' 3.7 (Etienne et al., 2012). We accounted for potential missing lineages in the phylogeny in the form of global sampling fraction, i.e. the ratio of sampled lineages diversity over the total described lineages, and ran these analyses for sampling fractions of $100 \%$ and $90 \%$. In 'RPANDA', we first fitted two constant-rate models as initial references, namely: BCST (speciation rate constant through time with no extinction) and BCSTDCST (speciation and extinction rates constant through time). Second, we fitted four time-dependent models: BtimeVar (speciation rate varying through time with no extinction), BtimeVarDCST (speciation rate varying through time with constant extinction), BCSTDtimeVar (constant speciation and extinction rate varying through time) and BtimeVarDtimeVar (both speciation and extinction rates varying through time).

342 Lastly, we fitted eight models with speciation and extinction rates varying according to external environmental variables: BtemperatureVar and Bsea-levelVar (speciation varying in 
344 function of the environmental variable), BtemperatureVarDCST and Bsea-levelVarDCST 345 (speciation varying in function of the variable with constant extinction rate),

346 BCSTDtemperatureVar and BCSTDsea-levelVar (extinction rate varying in function of the 347 variable and constant speciation rate) and BtemperatureVarDtemperatureVar and Bsea348 levelVarDsea-levelVar (both speciation and extinction rates varying in function of the 349 variable).

Exponential dependence with time, temperature or sea level and diversification rates are chosen for its robustness and flexibility depending on the strength and direction of the dependence to the fitted variable. Speciation $(\lambda)$ and extinction $(\mu)$ rates are parameterized as follows. When $\lambda$ and $\mu$ are exponential functions of sea level $(S)$ through time $(t)$, the equations are $\lambda\left(S_{(t)}\right)=\lambda_{0} \times e^{\alpha S(t)}$ and $\mu\left(S_{(t)}\right)=\mu_{0} \times e^{\beta S(t)}$, where $\lambda_{0}$ and $\mu_{0}$ are respectively the expected $\lambda$ and $\mu$ at $S=0$ meter, while $\alpha$ and $\beta$ are coefficients that measure the strength and the sign of the relationship with sea level (e.g. $\alpha>0$ and $\beta>0$ respectively indicate $\lambda$ and $\mu$ increase with sea level high stands). Similar parameterisation can be used for exponential relationship between temperature $(T)$ through time $(t)$ and $\lambda$ as well as $\mu$ rates in which $\lambda\left(T_{(t)}\right)=\lambda_{0}+\alpha T_{(t)}$ or $\lambda\left(T_{(t)}\right)=\lambda_{0} \times e^{\alpha T(t)}$, where $T(t)$ is the temperature at time $t$ and $\lambda_{0}$ is speciation rate at $T=0^{\circ} \mathrm{C}$.

The last three diversity-dependent ML models were fitted using 'DDD' package in which $\lambda$ and $\mu$ vary as linear functions of number of lineages within each clade (Etienne et al., 2012). The diversity-dependent models are parameterised by $\lambda_{0}, \mu_{0}$ (respectively indicating $\lambda$ and $\mu$ at the absence of competing lineage), $\mathrm{K}$ (carrying capacity, representing asymptotic clade size). All $\lambda$ and $\mu$ were constrained to be positive. The results were then compiled with the previous 14 models in 'RPANDA' and all are compared using corrected Akaike Information Criterion (AICc) and Akaike weights (AIC $\omega$ ). The model with the lowest AICc and highest AIC $\omega$ was considered as the best fitting model for the phylogeny.

\subsection{Ancestral areas estimation}

To explore dispersal and vicariance history based on the Paleoriver Hypothesis, we 372 reconstructed ancestral distribution of Sundaland Rasborinae using the R-package 373 'BioGeoBEARS' 1.1.2 (Matzke, 2014; Matzke, 2013) based on the StarBEAST2 MOTU 374 trees. Species presence/absence were compiled (Table S1) for two sets of geographical 375 delimitation based on: (1) paleoriver and (2) contemporary island boundaries. Then, geographical patterns of divergence were recorded as follows: (1) no dispersal, sister lineages 
co-occur within the same paleoriver and the same island; (2) dispersal between islands within 378 a paleoriver, sister lineages are alternatively distributed on different islands within the same 379 paleoriver; (3) dispersal between paleorivers within the same island, sister lineages are 380 alternatively distributed on different paleorivers within the same islands; and (4) dispersal 381 between islands and between paleorivers, sister lineages are alternatively distributed on different paleorivers and different islands. Ancestral area estimations involving paleorivers were based on the following geographical areas (Fig. 1): (1) the Malacca Straits paleoriver, (2) the East Sunda paleoriver, (3) the North Sunda paleoriver, (4) the Siam paleoriver, (5) the Northern Borneo river system, and (6) the Mekong river system. On the other hand, estimations based on insular delimitation followed geographical divisions of: (1) SumatraBangka-Belitung, (2) Java-Bali-Lombok, (3) Borneo, and (4) Mainland Southeast Asia. For 388 analytical requirements, only MOTUs with known localities that could be associated to both islands and palaeodrainages were used.

Inferences of the ancestral areas using 'BioGeoBEARS' were conducted using six alternative models including dispersal-extinction cladogenesis (DEC), DEC $+\mathrm{J}$, dispersalvicariance analysis ML-version (DIVALIKE), DIVALIKE $+\mathrm{J}$, Bayesian biogeographical inference model (BAYAREALIKE) and BAYAREALIKE+J (Matzke, 2014; Van Dam \& Matzke, 2016). The inclusion of the parameter $\mathrm{J}$ has been recently criticized from a 395 conceptual and statistical perspective (Ree \& Sanmartín, 2018). The concept of jumping dispersal has been developed for insular systems to account for the settlement of a new lineage established by colonization without an intermediate widespread ancestor (Clark et al., 2008; Ree \& Sanmartín, 2018). Considering the biogeographical scenario of Sundaland and the insularity of the system, jumping dispersal cannot be discarded a priori from a conceptual perspective and several studies have previously highlighted the importance of jumping 401 dispersal in insular systems (Beck et al., 2017; Condamine et al., 2015; Cowie \& Holland, 2006; de Bruyn et al., 2013; Hendriks, Alciatore, Schilthuizen, \& Etienne, 2019; Sholihah et al., 2021). Models of ancestral area estimation including the $\mathrm{J}$ parameters were thus considered here and the best-fit model was estimated using the AICc.

405

406

\section{RESULTS}

\subsection{Mitogenomes skimming}

Illumina sequencing yielded a number of reads ranging between 4.5 and 12 million per genomic libraries. A total of 58 new mitogenomes were successfully assembled with a minimum coverage of 10X for four genera including three Brevibora, one Pectenocypris, 45 
411 Rasbora and seven Trigonopoma. Mitogenomes were ca. 16,500 bp long on average and 412 include the coding regions of two rRNA (12S, 16S), 22 tRNA, 13 protein-coding genes and 413 the Control Region (CR). In addition, 10 Rasborinae mitogenomes were retrieved from 414 GenBank including the genera Amblypharyngodon, Horadandia, Rasboroides, Rasbora and 415 Boraras (Table S1). These 10 mitogenomes were used as reference genomes for assembly 416 and further phylogenetic reconstructions. An additional set of 11 mitogenomes was retrieved 417 from GenBank of Danionidae subfamilies and Cypriniformes families, which were used as 418 outgroups (Table S1). For phylogenetic reconstruction, tRNA coding regions and CR were 419 trimmed. The final alignment included 79 mitogenomes and 13,898 bp consisting of 2,518 bp 420 of rRNA and the 13 protein-coding regions including ND1 (975 bp), ND2 (1,045 bp), COI 421 (1551 bp), COII (691 bp), ATP8 (1655 bp), ATP6 (673 bp), COIII (785 bp), ND3 (349 bp), 422 ND4L (297 bp), ND4 (1,375 bp), ND5 (1,822 bp), ND6 (518 bp), and Cytb (1,134 bp).

423

424

425

\subsection{Reconstructing the backbone phylogeny of Rasborinae}

Phylogenetic reconstructions based on the 79 mitogenomes are well supported with 426 most internal branching events displaying posterior probabilities (PP) of $100 \%$ for the 427 Bayesian inference (Fig. 3A) and Bootstrap Proportions (BP) above $90 \%$ for the ML 428 reconstruction (Fig. 3B). Bayesian and ML topologies are congruent with continental Asian 429 Rasborinae (Amblypharingodon, Horadandia and Rasboroides) corresponding to the earliest 430 branching events in Rasborinae tree and Sundaland lineages constituting a monophyletic 431 432 group (Fig. 3). Four major clades are identified within Sundaland: (1) Clade I including the 433 genera Pectenocypris, Boraras, Trigonopoma and Rasbora kalbarensis; (2) Clade II including some Rasbora species; (3) Clade III including some Rasbora species; and (4) Clade

434 IV including some Rasbora species and the genera Brevibora and Trigonostigma. The 435 MRCA of Rasborinae dates back to ca. $46 \mathrm{Ma}$ (95\% HPD = 40-51 Ma, Eocene), while the 436 MRCA of the four Sundaland clades is dated at ca. 33 Ma (95\% HPD = 30-37 Ma, 437 Oligocene-Eocene transition). The four clades have varying age estimates with the MRCA of 438 Clade I dated at ca. $31 \mathrm{Ma},(95 \% \mathrm{HPD}=27-34 \mathrm{Ma}$, Oligocene), the MRCA of Clade II at ca. $43928 \mathrm{Ma}(95 \% \mathrm{HPD}=24-31 \mathrm{Ma}$, Oligocene), the MRCA of Clade III at ca. $26 \mathrm{Ma}$ (95\% HPD $440=23-30 \mathrm{Ma}$, Oligocene), and the MRCA of Clade IV at ca. $22 \mathrm{Ma}(95 \% \mathrm{HPD}=19.36-24.86$ 441 Ma, early Miocene). Estimated clock rates ranged between $0.31 \%$ per Myrs, with a variance 442 of $0.0017 \%$, for rRNA coding regions and $0.74 \%$ per Myrs, with a variance of $0.0048 \%$, for 443 protein-coding regions. Divergence time estimates were very similar with a birth-death model 
(Fig. S1). The MRCA of Sundaland Rasborinae is dated at ca. $33 \mathrm{Ma}(95 \%$ HPD = 30-37 $\mathrm{Ma}$ ), and divergence time estimates of descending nodes yielded very similar values. previously reported (Sholihah et al., 2020). COI sequence selection based on $80 \%$ BP threshold yielded 1,017 sequences, which together with the 66 Rasborinae mitogenomes sum up to 1,083 sequences for 71 nominal species, 157 MOTUs and 10 genera (Table S1). ML and Bayesian gene trees are congruent for all clades (Fig. 4). Most internal branching events are well supported in the ML gene trees (Figs. 4A, 4C, 4E, 4G), except among some Trigonopoma MOTUs within Clade I (Fig. 4A), and the most derived MOTUs of Clade IV (Fig. 4G). Bayesian gene trees were more supported for all clades (Figs. 4B, 4D, 4F, 4H) with most internal branching events supported by $\mathrm{PP}>0.9$. The estimated mitogenome clock rate was $0.55 \%$ per Myrs for Clade I, $0.64 \%$ per Myrs for Clade II, $0.51 \%$ per Myrs for Clade III, and $0.56 \%$ per Myrs for Clade IV. According to the backbone phylogeny analysis and 459 subsequent MRCA age calibrations, several clades are identified and labelled as clades I-IV. In clade I, three subclades are observed: (1) Pectenocypris spp., with an MRCA dated at ca. 8 Ma (95\% HPD = 4-13 Ma), (2) Boraras spp., with a MRCA dated at ca. 24 Ma $(95 \%$ HPD = 19-28 Ma), and (3) Trigonopoma spp., including Kottelatia britani and Rasbora kalbarensis, with a MRCA dated at ca. $26 \mathrm{Ma}(95 \% \mathrm{HPD}=24-27 \mathrm{Ma})$. In clade II, two subclades are observed: (1) R. lacrimula, $R$. semilineata, $R$. hubbsi, $R$. rutteni and $R$. sarawakensis, with a MRCA dated at ca. $16 \mathrm{Ma}(95 \% \mathrm{HPD}=14-18 \mathrm{Ma})$, and (2) all remaining species within 466 clade II, with a MRCA dated at ca. $25 \mathrm{Ma}(95 \% \mathrm{HPD}=24-27 \mathrm{Ma})$. In clade III, two clades can be identified: (1) R. cephalotaenia MOTUs, with a MRCA dated at ca. $8 \mathrm{Ma}$ (95\% HPD =5-11 Ma), and (2) all remaining species within clade III, with a MRCA dated at ca. $21 \mathrm{Ma}$ (95\% HPD = 19-24 Ma). In clade IV, three subclades can be identified: (1) Rasbora tornieri and $R$. dusonesis, with a MRCA dated at ca. $17 \mathrm{Ma}(95 \% \mathrm{HPD}=12-21 \mathrm{Ma}),(2) R$. myersi, $R$. borapetensis, $R$. sumatrana and $R$. argyrotaenia, with a MRCA dated at ca. 15 Ma (95\% HPD $=13-26 \mathrm{Ma}$ ), and (3) all other Rasbora species within the clade, starting from $R$. trilineata, with a MRCA dated at ca. $19 \mathrm{Ma}(95 \% \mathrm{HPD}=18-20 \mathrm{Ma})$.

\subsection{Diversification rates estimation}


478

479

480

481

482

483

484

485

486

487

488

489

490

491

492

493

494

495

496

497

498

499

500

501

502

503

504

505

506

507

508

509

510

among clades with $55 \%$ of MOTUs with a Pleistocene origin in Clade IV, $50 \%$ in Clade III, $41 \%$ in Clade I and 36\% in Clade II. Best-fit diversification models indicate no clade-specific patterns of diversification (Table S3). The constant speciation rate without extinction (BCST) model is the most likely for all clades (AIC $\omega$ of 0.23 for Clades I and II, 0.262 for Clade III, and 0.22 for Clade IV), with both sampling fractions used (Table 1, Table S3). Speciation rates are similar for Clades I, II and III with $\lambda=0.0898,0.108,0.1195$ events/Myr/lineage, respectively (Table 1, Fig. S2). Clade IV, however, shows a higher rate of speciation with $\lambda=$ 0.147 (Table 1, Fig. S2).

\subsection{Ancestral areas estimation}

A total of 139 MOTUs from 60 nominal species with known geographical distribution were used for ancestral area estimations for the four clades (Fig. 5, Fig. S4). The most likely biogeographical models include the $\mathrm{J}$ parameter for all clades and both island-based and paleoriver-based geographical partitioning (Table S4). DEC $+\mathrm{J}$ is the most likely model in most cases, except for Clade III with the paleoriver-based partitioning supporting the DIVALIKE $+\mathrm{J}$ model. Ancestral area estimations point to Borneo as the most likely origin of Clades II and IV and subclades of Clade II, with a high probability of Bornean ancestry of their MRCAs (Figs. 5B, 5C, 5D). The insular ancestry of Clade I is not resolved, but the North Sundaland paleoriver is identified as the most likely origin of Clade I (Fig. 5A) as well as Clades II and IV (Figs. 5B, 5D). Ancestral areas estimation indicates a recent colonization of Java during the Pliocene (ca. $4 \mathrm{Ma}$ ) by Clade IV (Fig. 5D). In situ diversification is observed in all clades, particularly in Borneo (island-based analyses) and North Sunda (in paleoriver-based analyses) as exemplified by the upper group of Clade II (Rasbora lacrimula, R. hubsii, R. semilineata, R. sarawakensis, R. rutteni) from Borneo (ca. 16 Ma, 95\% HPD = 14-18 Ma), as well as Trigonopoma gracile MOTU144-MOTU148 (ca. 6 Ma, 95\% HPD = 3$9 \mathrm{Ma}$ ) and Trigonopoma pauciperforatum MOTU154-MOTU157 (ca. 4 Ma, 95\% HPD = 2-6 Ma) from North Sunda (Fig. 5).

Several dispersal pathways are identified between Sundaland and Asia mainland, and within Sundaland (Table 2, Figs. $5 \&$ 6). Between 31-17.5 Ma, two pathways are identified: (a) between Borneo and Asia mainland, and (b) Borneo and Sumatra. Between 17.5-7.5 Ma, four pathways are identified: (a) between Borneo and Asia mainland, (b) between Borneo and Sumatra, (c) between Sumatra and Asia, and (d) between North and East Sunda paleorivers within Borneo. Between 7.5-0 Ma, eight pathways are identified: (a) between Borneo and 
511 Asia mainland, (b) between Borneo and Sumatra, (c) between Sumatra and Asia mainland,

512 (d) between North and East Sunda paleorivers within Borneo, (e) between North Sunda and

513 Malacca paleorivers within Sumatra, (f) between Sumatra (North Sunda paleoriver) and Asia

514 mainland, (g) between Sumatra and Java, and (h) between Borneo and Java. Several burst of

515 in situ mitochondrial lineage diversification are detected within Borneo since the Early

516 Miocene, and within Sumatra and Java since the early Pliocene (Fig. 6).

517 In total, most mitochondrial lineage diversification events are observed within islands

518 with 59\% and between paleorivers with 54\% (Table 3, Fig. S3). Most divergence events are 519 associated to dispersal as $66 \%$ involve either different islands or different paleorivers, while $52034 \%$ occurred within the same island and the same paleoriver (Table 2). However, these 521 trends vary through time. Most lineage divergence between islands occurs during the last 5

522 Myrs and is mostly associated to dispersal between paleorivers (Fig. S3A). Along the same 523 line, in situ divergence within paleoriver occurs mostly within island during the last 5 Myrs

524 (Fig. S3A). Geographical patterns of divergence vary among clades with a spectacular 525 dominance of divergence within islands for Clade II, most frequently occurring within the 526 same paleoriver (Table 2, Fig. S3C). Proportions are more balanced for other clades (Table

527 2), with most divergence events within paleorivers occurring within islands (Fig. S3).

528

529

\section{DISCUSSION}

530

531

\subsection{Sundaland biogeography}

532

Our phylogenetic and biogeographic reconstructions support the hypothesis of mostly in situ diversity build-up of Rasborinae within Sundaland, with limited connections between Sundaland and Asia mainland, during a timeframe consistent with geological reconstructions

535 Rasborinae lineages from mainland Asia are associated with the earliest branching events at 536 the root of the Rasborinae phylogenetic reconstructions. Our divergence time estimate of 537 Sundaland clades indicates that the four Sundaland lineages started to diversify between ca. 538 31-22 Ma, during the isolation of Borneo from mainland Asia (Fig. 1). These age estimates 539 are consistent with a single origin of Sundaland Rasborinae through in situ diversification as evidenced by the phylogenetic reconstructions supporting their monophyly. Ancestral area

541 estimations further confirm this scenario as Borneo is inferred as the most likely origin of 542 most Sundaland clades (Fig. 5) and also the only island supporting early Miocene in situ 543 diversification (Fig. 6A: 1). These results suggest Rasborinae of Sundaland originate from 544 mainland Asia in the Oligocene, when Borneo was still part of mainland Asia, and 
545 diversification of the four clades started during the isolation of Borneo. This timeframe 546 supports the pre-Pleistocene colonisation of Sundaland by freshwater fishes (de Bruyn et al., 547 2013; Dodson et al., 1995; Sholihah et al., 2021), as previously reported in insular Southeast 548 Asia (Brown et al., 2013), followed by subsequent dispersal and divergence during the 549 emergence of Sumatra and Java (Fig. 6).

550 Our biogeographic estimations further highlight the importance of the North Sunda 551 paleoriver during the initial freshwater fish diversification in Sundaland (de Bruyn et al. 552 2013, 2014). The North Sunda paleoriver is the most likely centre of origin of most 553 Rasborinae clades (Fig. 4) and also the part of Borneo involved in the highest number of 554 dispersal pathways during the late Miocene (Fig. 6B: a, b and d) and early Pliocene (Fig. 6C: $555 \mathrm{a}, \mathrm{b}$ and $\mathrm{d}$ ). The diversification of Rasborinae mitochondrial lineages further followed 556 Sundaland's geological history with various colonization scenarios for Sumatra and Java. 557 Java is the youngest of Sundaland islands, with a separation that occurred during the last 5 558 Myrs (Fig. 1), which is consistent with our divergence time estimates as none of the MOTUs 559 endemic of Java are older than ca. 4 Myrs (Rasbora sp. 2). However, our reconstructions 560 indicate that colonization of Java likely results from at least two distinct immigration events 561 (Fig. 6C: g, h) followed by in situ diversification (Fig. 6C: 1). Immigration followed by in 562 situ lineage diversification has been previously suggested for freshwater fishes in Java, 563 including Rasbora (Hubert et al., 2019; Hutama et al., 2017; Kusuma et al., 2016). These 564 divergence events are likely resulting from the intense volcanic activity in Java, which 565 formed several volcanic arches and fragmented rivers into multiple, small and confined 566 watersheds during the Pliocene and Pleistocene. Java is the only island of Sundaland with a predominant influence of volcanic activity during its emergence (Lohman et al., 2011). These rugged aquatic landscapes likely fragmented ancestral lineages, creating local radiations within the island (Nguyen et al. 2008; Pouyaud et al. 2009; Hubert et al. 2015, 2019; Kusuma et al. 2016; Dahruddin et al. 2017; Hutama et al. 2017).

This scenario in Java contrasts with Sumatra, which biogeographic estimations 572 suggest a more ancient and intricate scenario of colonization (Fig. 6). Two ancient lineages 573 are detected in Sumatra: Rasbora kalbarensis diverged ca. $23 \mathrm{Ma}$, and R. jacobsoni diverged 574 ca. $20 \mathrm{Ma}$. These lineages occur in the North Sunda or Malacca paleorivers (Fig. 5). The age 575 estimates of these species contrast with most lineages in Sumatra, not exceeding ca. 13 Myrs 576 and mostly tracing back to the Miocene-Pliocene transition ca. 5 Ma. These contrasted 577 patterns suggest two waves of colonization during: (1) the onset of Borneo isolation and the 578 emergence of the first volcanic arches in Sumatra during the early Miocene (Fig. 6A: b), and 
579 (2) the final stage of isolation of Sumatra, when land bridges were still connecting the 580 Southern tip of Sumatra, Borneo and West Java during the late Miocene (Fig. 6B: b, c). Cases

581 of in situ diversification are also detected in Sumatra during the Pliocene (Fig. 6C: 2).

\subsection{Dispersal and Pleistocene palaeoenvironments}

585

586

587

588

589

590

591

592

593

594

595

596

597

598

599

600

601

602

603

604

605

606

607

608

609

610

611

612

Our ancestral area estimations and modelling of lineage divergence and dispersal indicate jump dispersal is common in Rasborinae, a result supported by the significant increase of likelihood scores and Akaike weights when the $J$ parameter is included (Table S4). Multiple cases of trans-island dispersal have been reported among Sundaland freshwater fishes (Adamson, Hurwood, \& Mather, 2010; Beck et al., 2017; de Bruyn et al., 2013; Lim et al., 2016; Farhana et al., 2018; Pouyaud et al., 2009; Sholihah et al., 2021; Tan \& Lim, 2013). However, our reconstructions question Pleistocene sea level changes as a main driver of dispersal between islands. During glacial maxima, sea levels dropped (Miller et al., 2005). The shallow Java Sea has given way to exposed lands, which likely had freshwater drainage systems that extended between modern islands (Voris, 2000; Woodruff, 2010). These paleoriver systems are expected to ease dispersal between islands and promote divergence (Fig. 2). This prediction received little support here. Most mitochondrial divergence events occurred within islands (Table 3) and most divergence events between islands occurred between paleorivers (Fig. S3). The predominance of divergence within islands is likely linked to Rasborinae ecology. Most species in Clades I, II, and III are small-size species inhabiting forested streams and peat swamps (Kottelat, Whitten, Kartikasari, \& Wirjoatmodjo, 1993; Sholihah et al., 2020). These species are forest-dependent taxa with limited dispersal abilities.

During glacial maxima, climate was cooler and drier. Savanna and seasonal forest corridors expanded through the interior of Sundaland (Bird et al., 2005; Heaney, 1992), enhancing microclimates and diversity of freshwater habitats along the inter-island channels (Bird et al., 2005; Gorog, Sinaga, \& Engstrom, 2004; Heaney, 1992; Pouyaud et al., 2009; Wurster et al., 2019). While documented for terrestrial organisms, divergence pattern of Clade II suggests that vegetational changes during glacial maxima also limited dispersal for aquatic, forest-associated organisms. Clade II further exemplifies the intricate interactions between palaeoenvironments and dispersal. Habitat specificity toward forest habitats and peat swamps may have limited dispersal between islands despite the availability of freshwater corridors. These results highlight the dynamic interactions between palaeoenvironments and Pleistocene sea level changes (Esselstyn and Brown 2009; Brown et al. 2013; Papadopoulou and Knowles 2015a, 2015b). 


\subsection{Macroevolutionary drivers of diversification}

Pleistocene climatic fluctuations have been frequently invoked to account for

616 Pleistocene increased rates of diversification (Mittelbach et al., 2007; Weir \& Schluter,

617 2007). In Sundaland, Pleistocene sea level changes are predicted to induce cycle of dispersal

618 during glacial time and vicariance during interglacial periods (Kottelat et al., 1993; Voris,

619 2000; Woodruff, 2010). An amplification of sea-level fluctuations during the Pleistocene has

620 been observed (Fig. 1) (Miller et al., 2005), which predict increased rates of lineage

621 divergence in the context of Sundaland (Fig. 2). This prediction is not supported here.

622 Constant lineage divergence models of diversification are the most likely for all clades (Fig.

623 S2; Table S3). In a model with a constant probability of divergence per lineage through time,

624 lineage diversity increases linearly over time without levelling off toward the present (Table

625 S2). Thus, the Pleistocene origin of a large proportion of lineages could be a consequence of

626 constant diversification through time. This result might be surprising when considering the

627 vast array of aquatic habitats occupied by Rasborinae in Sundaland: lowland vs. highland,

628 fast vs. slow running waters, peat swamps, lakes, ponds (Brittan, 1972; Hubert et al., 2019;

629 Kottelat et al., 1993; Kusuma et al., 2016; Sholihah et al., 2020). Besides, ecological

630 transitions are scarce in Rasborinae. Clades I, II and III include small-size, forest-associated

631 species while Clade IV include all the large, riverine and open-habitat Rasbora species

632 (Kottelat et al., 1993; Liao et al., 2011; Sholihah et al., 2020). This pattern suggests that

633 adaptive habitat-shift had limited impact on the pace of diversification in Rasborinae. Yet,

634 Clade IV has the highest diversification rate of the four clades and is also the only clade that

635 colonized Java. Altogether, the transition between forest and open habitat, which happened

636 during the onset of Clade IV diversification, and higher divergence rate suggest an influence

637 of ecological contingency on Rasborinae diversification. This group of riverine and

638 opportunistic species was successful at colonizing open habitats, a previously non-colonized

639 set of habitats for Rasborinae.

640 Despite the high diversity of mitochondrial lineages in Sundaland Rasborinae, we find 641 no evidence of diversity equilibrium. The diversity-dependent diversification models received

642 little support for all clades, suggesting intra-clade biotic interactions have little influence on

643 either divergence opportunities or probabilities of maintenance of newly emerging lineages

644 (Alonso, Etienne, \& McKane, 2006; Hubert, Calcagno, Etienne, \& Mouquet, 2015). If

645 considering the ample distribution and abundance of Rasborinae in Sundaland and their

646 presence in all aquatic habitats, this result is surprising. Rasborinae assemblages were likely 
unsaturated during the diversification of the subfamily (Cornell, 1993). Diversity equilibrium and slowdown of diversification rates implies a shift in divergence/extinction equilibriums once assemblages are saturated (Hubert, Calcagno, et al., 2015; Kisel, McInnes, Toomey, \& Orme, 2011; Phillimore \& Price, 2008). Here, PCFs might be expected to have cyclically perturbed aquatic assemblages, and regularly disrupted a potential course toward equilibrium. Alternatively, Sundaland ecological carrying capacity might still be far from being reached, despite the staggering species richness of Sundaland ichthyofauna.

\subsection{Robustness of the inferences and systematic implications}

Our study first confirms the monophyly of the subfamily Rasborinae and its distinctiveness from the subfamilies Chedrinae, Danioninae and Esominae (Conway, Chen, \& Mayden, 2008; Fang, Norïn, Liao, Källersjö, \& Kullander, 2009; Mayden et al., 2007; Rüber, Kottelat, Tan, Ng, \& Britz, 2007; Tan \& Armbruster, 2018; Tang et al., 2010). Our cladespecific phylogenetic reconstructions confirm the monophyly of the genera Boraras, Pectenocypris and Trigonostigma, but also support the paraphyly of the genus Trigonopoma, and the polyphyly of the genera Brevibora and Rasbora. The polyphyly of Rasbora is in line with previous molecular and morphology-based phylogenetic studies, which highlighted that Rasbora encompasses several lineages of distinct evolutionary origins (Liao et al., 2010, 2011; Lumbantobing, 2010; Sholihah et al., 2020; M. Tan \& Armbruster, 2018; K. L. Tang et al., 2010). Yet, most Rasbora species groups initially described by Brittan $(1954,1972)$ are recovered. For instance, Clade III matches the delimitation of $R$. einthovenii species group and Clade II matches the boundaries of $R$. trifasciata species group (Brittan, 1972; Liao et al., 2010). We also support the elevation of $R$. pauciperforatum species group to the genus level (Trigonopoma) by Liao et al (2010). However, our results indicate $R$. kalbarensis should probably be considered a member of the genus Trigonopoma. Likewise, the genus Boraras

672 described by Kottelat and Vidthayanon (Kottelat \& Vidthayanon, 1993) is supported here. 673 Most of the taxonomic conflicts are concentrated in Clade IV, in which $R$. lateristriata and $R$. sumatrana species groups from Brittan (1972), and the genus Brevibora from Liao et al (2011) are not monophyletic. The present study warrants further taxonomic works within Rasborinae and highlights the need of an in-depth revision of the genera Rasbora and 677 Brevibora. mitochondrial and 20 nuclear genes. However, these results are not concordant with the ray- 
681 finned fishes phylogeny of Rabosky et al. (2018) dating the MRCA of Rasborinae at 59 Ma, 682 and the MRCA of Sundaland Rasborinae at 42 Ma. Several differences in the calibration 683 methods and molecular markers may account for these differences. Phylogenetic 684 reconstructions of Rabosky et al. (2018) are based on 20 nuclear markers. Discordances 685 between mitochondrial and nuclear markers might be expected due to the maternal 686 inheritance of mitochondrial genomes, with potential cryptic past introgression events and 687 selective sweeps leading to conflicting phylogenetic reconstructions (Hubert, Torrico, 688 Bonhomme, \& Renno, 2007; Ríos, Bouza, \& García, 2019; Wallis et al., 2017). Rabosky et 689 al. (2018) and our phylogenetic reconstructions yielded concordant deep phylogenetic 690 relationships, with lineages of Asia mainland (Amblypharyngodon, Horadandia and 691 Rasboroides) placed in basal positions, and Sundaland lineages being equally assorted into 692 the four clades I-IV. However, discordance between mitochondrial and nuclear markers due 693 to past introgression cannot be discarded for shallower phylogenetic scales, hybridization 694 being common in Cypriniformes (Atsumi, Nomoto, Machida, Ichimura, \& Koizumi, 2018; 695 Hopkins \& Eisenhour, 2008; Tang, Liu, Yu, Liu, \& Danley, 2012). Discrepancies in the age 696 estimate of Rasborinae MRCA are most likely due to the use of alternative calibration methods. Rabosky et al. (Rabosky et al., 2018) fossil calibrations are scarce for 698 Cypriniformes, with only three, distantly related from Rasborinae and ancient fossils 699 (†Amyzon aggregatum for the North American Catostomidae dated between 49-122 Ma, 700 †Cyprinus maomingensis for Eurasia Cyprini dated between 40-98 Ma, and 701 †Huashancyprinus robustispinus for Eurasia Cyprinus dated between 23-73 Ma). The 702 Rasborinae MRCA age estimate proposed by Rabosky et al. (2018) implies a markedly 703 different biogeographic scenario, with Rasborinae diversification originating much before the 704 isolation of Borneo. This ancient origin is not supported by recent phylogenetic reconstructions among the Cypriniformes genera Nemacheilus and Pangio in Southeast Asia, which MRCAs were recently dated at ca. $20 \mathrm{Ma}$ according to phylogenetic reconstructions based on both mitochondrial and nuclear markers (Šlechtová et al., 2021). Along the same line, a recent reappraisal of previously published phylogenetic reconstructions support an early to late Miocene origin of several Southeast Asian fish taxa (Sholihah et al., 2021).

\section{CONCLUSION}

Pleistocene sea level changes had less impact on Rasborinae diversification than 713 expected under the Paleoriver Hypothesis. Geographical patterns of divergence suggest that 714 limited dispersal abilities and in situ diversification were predominant during the diversity 
715 build-up of Rasborinae in Sundaland. Our phylogenetic and biogeographic reconstructions

716 are in line with the timeframe of geological reconstructions in Southeast Asia. The

717 Rasborinae followed the geological history of Sundaland and tightly matched the onset of

718 isolation of Borneo. In particular, the North Sunda paleoriver is identified as a key aquatic

719 system during the rise of the group and an important source of diversity for the neighbouring

720 river systems. Our study also provides new lines of evidence about dispersal of freshwater

721 organisms in Sundaland. Paleoriver watershed boundaries poorly explain geographical

722 patterns of divergence and dispersal between islands. Surprisingly, our macroevolutionary

723 inferences show no evidence of diversification slowdown and diversity ceiling, despite the

724 exceptional levels of species richness of Sundaland ichthyofauna. This unexpected result

725 further questions the mechanisms underlying these diversification trends. Several alternative

726 scenarios may be invoked, including the impact of PCFs on disturbing speciation/extinction

727 equilibriums. Our study warrants further research on the evolutionary mechanisms underlying

728 diversification in such species-rich tropical systems.

729

730 Acknowledgements

731 The authors wish to thank Siti Nuramaliati Prijono, Bambang Sunarko, Witjaksono,

732 Mohammad Irham, Marlina Adriyani, Ruliyana Susanti, Rosichon Ubaidillah, the late Renny

733 K. Hadiaty, Hari Sutrisno and Cahyo Rahmadi at Research Centre for Biology (RCB-LIPI) in

734 Indonesia; Edmond Dounias, Jean-Paul Toutain, Robert Arfi and Valérie Verdier from the

735 'Institut de Recherche pour le Développement'; Joel Le Bail and Nicolas Gascoin at the

736 French embassy in Jakarta for their continuous support. We also would like to thank Eleanor

737 Adamson, Hendry Budianto, Tob Chann Aun, Pak Epang, Herman Ganatpathy, Renny K

738 Hadiaty, Sébastien Lavoué, Michael Lo, Hendry Michael, Sopian Sauri, Joshua Siow, Heok

739 Hui Tan, Elango Velautham, Norsham S. Yaakob, and Denis Yong for their help in the field.

740 We are also particularly thankful to Sumanta at IRD Jakarta for his help during the field

741 sampling in Indonesia. The present study and all associated methods were carried out in

742 accordance with relevant guidelines and regulation of the Indonesian Ministry of Research

743 and Technology (Indonesia), the Economic Planning Unit, Prime Minister's Department

744 (Malaysia), the Forest Department Sarawak (Malaysia), the Vietnam National Museum of

745 Nature (Vietnam) and the Inland Fisheries Research and Development Institute (Cambodia).

746 Field sampling in Indonesia was conducted according to the research permits

747 7/TKPIPA/FRP/SM/VII/2012, 68/EXT/SIP/FRP/SM/VIII/2013,

748 41/EXT/SIP/FRP/SM/VIII/2014, 361/SIP/FRP/E5/Dit.KI/IX/2015, 

392/SIP/FRP/E5/Dit.KI/XI/2018 for Nicolas Hubert, and, 1/TKPIPA/FRP/ SM/I/2011 and 3/TKPIPA/FRP/SM/III/2012 for Lukas Rüber. The Fieldwork in Peninsular Malaysia and

752 Sarawak was conducted under permits issued by the Economic Planning Unit, Prime 753 Minister's Department, Malaysia (UPE 40/200/19/2417 and UPE 40/200/19/2534) and the 754 Forest Department Sarawak (NCCD.970.4.4[V]-43) and were obtained with the help of 755 Norsham S. Yaakob (Forest Research Institute Malaysia, Kepong, Kuala Lumpur, Malaysia). 756 Luong Van Hao and Pham Van Luc (Vietnam National Museum of Nature) helped with 757 arranging research permits in Vietnam and So Nam (Inland Fisheries Research and Development Institute, IFReDI) helped with arranging research permits in Cambodia. All 759 experimental protocols were approved by the Indonesian Ministry of Research and 760 Technology (Indonesia), the Indonesian Institute of Sciences (Indonesia), the Forest Department Sarawak (Malaysia), Economic Planning Unit of the Prime Minister's Department (Malaysia), the Vietnam National Museum of Nature (Vietnam) and the Inland

763

764 Fisheries Research and Development Institute (Cambodia). This publication has ISEM number 2021-062 SUD.

765

766

767

768

769

770

771

\section{References}

773 Adamson, E. A. S., Hurwood, D. A., \& Mather, P. B. (2010). A reappraisal of the evolution 774 775 776

777 778

\section{Data availability statement}

DNA barcodes are available in the Barcode of Life Data System (dx.doi.org/110.5883/DSBIFRA) and GenBank (see Table S1 for accession numbers). Mitogenomes are available in GenBank (see Table S1 for accession numbers). Phylogenetic reconstructions and DNA sequence alignments are available in Dryad (doi.org/10.5061/dryad.tb2rbp00g). of Asian snakehead fishes (Pisces, Channidae) using molecular data from multiple genes and fossil calibration. Molecular Phylogenetics and Evolution, 56(2), 707-717. https://doi.org/10.1016/j.ympev.2010.03.027

Alonso, D., Etienne, R. S., \& McKane, A. J. (2006). The merits of neutral theory. Trends in Ecology and Evolution, 21(8), 451-457. https://doi.org/10.1016/j.tree.2006.03.019

Atsumi, K., Nomoto, K., Machida, Y., Ichimura, M., \& Koizumi, I. (2018). No reduction of hatching rates among F1 hybrids of naturally hybridizing three Far Eastern daces, genus 
782

783

784

785

786

787

788

789

790

791

792

793

794

795

796

797

798

799

800

801

802

803

804

805

806

Barraclough, T. G., \& Nee, S. (2001). Phylogenetics and Speciation. Trends in Ecology and Evolution, 16(7), 391-399.

Beck, S. V., Carvalho, G. R., Barlow, A., Ruber, L., Hui Tan, H., Nugroho, E., ... de Bruyn, M. (2017). Plio-Pleistocene phylogeography of the Southeast Asian Blue Panchax killifish, Aplocheilus panchax. PLoS One, 12(7), e0179557. https://doi.org/10.1371/journal.pone.0179557

Bermingham, E., McCafferty, S., \& Martin, A. P. (1997). Fish biogeography and molecular clocks: perspectives from the Panamanian isthmus. In T. D. Kocher \& C. A. Stepien (Eds.), Molecular systematics of fishes (pp. 113-128). San Diego: CA Academic Press.

Bernatchez, L., \& Wilson, C. (1998). Comparative phylogography of Neartic and Paleartic fishes. Molecular Ecology, 7, 431-452.

Betancur-R, R., Wiley, E. O., Arratia, G., Acero, A., Bailly, N., Miya, M., ... Ortí, G. (2017). Phylogenetic classification of bony fishes. BMC Evolutionary Biology, 17(1), 162. https://doi.org/10.1186/s12862-017-0958-3

Bird, M. I., Taylor, D., \& Hunt, C. (2005). Palaeoenvironments of insular Southeast Asia during the Last Pleistocene. Glacial Period: a savanna corridor in Sundaland? . Quaternary Science Reviews, 24, 2228-2242.

Blaxter, M., Mann, J., Chapman, T., Thomas, F., Whitton, C., Floyd, R., \& Abebe, E. (2005). Defining operational taxonomic units using DNA barcode data. Philosophical Transactions of the Royal Society B: Biological Sciences, 360(1462), 1935-1943.

Bouckaert, R., Heled, J., Kühnert, D., Vaughan, T., Wu, C. H., Xie, D., ... Drummond, A. J. (2014). BEAST 2: A Software Platform for Bayesian Evolutionary Analysis. PLoS Computational Biology, 10(4), 1-6. https://doi.org/10.1371/journal.pcbi.1003537

Brittan, M. R. (1954). A revision of the Indo-Malayan frash-water fish genus Rasbora. Monogr. Inst. Sci. Tech. Manila, 3, 3-pls.

807 Brittan, M. R. (1972). Rasbora: A revision of the Indo-Malayan freshwater fish genus 
809 Brown, R. M., Siler, C. D., Oliveros, C. H., Esselstyn, J. A., Diesmos, A. C., Hosner, P. A., 810 ... Alcala, A. C. (2013). Evolutionary Processes of Diversification in a Model Island Archipelago. Annual Review of Ecology, Evolution, and Systematics, 44(1), 411-435. https://doi.org/10.1146/annurev-ecolsys-110411-160323

813 Cannon, C. H., Morley, R. J., \& Bush, M. B. (2009). The current refugial rainforests of Sundaland are unrepresentative of their biogeographic past and highly vulnerable to disturbance. Proceedings of the National Academy of Sciences, USA, 106(27), 1118811193.

817

818

819

820

821

822

823

824

825

826

827

828

829

830

831

832

833

834

Chang, J., Rabosky, D. L., Smith, S. A., \& Alfaro, M. E. (2019). An r package and online resource for macroevolutionary studies using the ray finned fish tree of life. Methods in Ecology and Evolution, 10(7), 1118-1124.

Clark, J. R., Ree, R. H., Alfaro, M. E., King, M. G., Wagner, W. L., \& Roalson, E. H. (2008). A comparative study in ancestral range reconstruction methods: retracing the uncertain histories of insular lineages. Systematic Biology, 57(5), 693-707.

Condamine, F. L., Rolland, J., \& Morlon, H. (2013). Macroevolutionary perspectives to environmental change. Ecology Letters, 16(SUPPL.1), 72-85. https://doi.org/10.1111/ele.12062

Condamine, F. L., Rolland, J., \& Morlon, H. (2019). Assessing the causes of diversification slowdowns: temperature-dependent and diversity-dependent models receive equivalent support. Ecology Letters, 22(11), 1900-1912. https://doi.org/10.1111/ele.13382

Condamine, F. L., Sperling, F. A. H., Wahlberg, N., Rasplus, J., \& Kergoat, G. J. (2012). What causes latitudinal gradients in species diversity? Evolutionary processes and ecological constraints on swallowtail biodiversity. Ecology Letters, 15(3), 267-277.

Condamine, F. L., Toussaint, E. F. A., Clamens, A. L., Genson, G., Sperling, F. A. H., \& Kergoat, G. J. (2015). Deciphering the evolution of birdwing butterflies 150 years after Alfred Russel Wallace. Scientific Reports, 5, 1-11. https://doi.org/10.1038/srep11860 
835 Condamine, F. L., Toussaint, E. F. A., Cotton, A. M., Genson, G. S., Sperling, F. A. H., \& Kergoat, G. J. (2013). Fine scale biogeographical and temporal diversification processes of peacock swallowtails (Papilio subgenus Achillides) in the Indo Australian Archipelago. Cladistics, 29(1), 88-111.

839 Conway, K. W., Chen, W.-J., \& Mayden, R. L. (2008). The "Celestial Pearl danio" is a

840

841

842

843

844

845

846

847

848

849

850

851

852

853

854

855

856

857

858

859

860

861

862

863 miniature Danio (s.s.) (Ostariophysi: Cyprinidae): evidence from morphology and molecules. Zootaxa, 1686, 1-28.

Cornell, H. V. (1993). Unsaturated patterns in species assemblages: the role of regional processes in setting local species richness. In R. E. Ricklefs Schluter, D (Ed.), Species diversity in ecological communities: historical and geographical perspectives (pp. 243252). Chicago: University of Chicago Press.

Cowie, R. H., \& Holland, B. S. (2006). Dispersal is fundamental to biogeography and the evolution of biodiversity on oceanic islands. Journal of Biogeography, 33(2), 193-198. https://doi.org/10.1111/j.1365-2699.2005.01383.x

Dahruddin, H., Hutama, A., Busson, F., Sauri, S., Hanner, R., Keith, P., ... Hubert, N. (2017). Revisiting the ichthyodiversity of Java and Bali through DNA barcodes: taxonomic coverage, identification accuracy, cryptic diversity and identification of exotic species. Molecular Ecology Resources, 17(2), 288-299. https://doi.org/10.1111/17550998.12528

de Bruyn, M., Rüber, L., Nylinder, S., Stelbrink, B., Lovejoy, N. R., Lavoué, S., ... Carvalho, G. R. (2013). Paleo-drainage basin connectivity predicts evolutionary relationships across three Southeast asian biodiversity hotspots. Systematic Biology, 62(3), 398-410.

de Bruyn, M., Stelbrink, B., Morley, R. J., Hall, R., Carvalho, G. R., Cannon, C. H., ... von Rintelen, T. (2014). Borneo and Indochina are Major Evolutionary Hotspots for Southeast Asian Biodiversity. Syst Biol, 63(6), 23. https://doi.org/10.5061/dryad.67s40

Dodson, J. J., Colombani, F., \& Ng, P. K. L. (1995). Phylogeographic structure in mitochondrial DNA of a South-east Asian freshwater fish, Hemibagrus nemurus (Sluroidei; Bagridae) and Pleistocene sea-level changes on the Sunda shelf. Molecular Ecology, 4, 331-346. 
864

865

866

867

868

869

870

871

872

873

874

875

876

877

878

879

880

881

882

883

884

885

886

887

888

889

890

Dodsworth, S. (2015). Genome skimming for next-generation biodiversity analysis. Trends in Plant Science, 20(9), 525-527.

Drummond, A., Suchard, M., Xie, D., \& Rambault, A. (2012). Bayesian phylogenetics with BEAUti and the BEAST 1.7. Molecular Biology and Evolution, 29(1969-1973).

Durand, J., Persat, H., \& Bouvet, Y. (1999). Phylogeography and postglacial dispersion of the chub (Leuciscus cephalus) in Europe. Molecular Ecology, 8, 989-997.

Eschmeyer, W. N., Fricke, R., \& van der Laan, R. (2018). Catalog of fishes electronic version (C. A. of Sciences, Ed.).

Esselstyn, J. A., \& Brown, R. M. (2009). The role of repeated sea-level fluctuations in the generation of shrew (Soricidae: Crocidura) diversity in the Philippine Archipelago. Molecular Phylogenetics and Evolution, 53(1), 171-181. https://doi.org/10.1016/j.ympev.2009.05.034

Esselstyn, J. A., Timm, R. M., \& Brown, R. M. (2009). Do geological or climatic processes drive speciation in dynamic archipelagos? the tempo and mode of diversification in southeast asian shrews. Evolution, 63(10), 2595-2610. https://doi.org/10.1111/j.15585646.2009.00743.x

Etienne, R. S., Haegeman, B., Stadler, T., Aze, T., Pearson, P. N., Purvis, A., \& Phillimore, A. B. (2012). Diversity-dependence brings molecular phylogenies closer to agreement with the fossil record. Proceedings of the Royal Society B: Biological Sciences, 279(1732), 1300-1309. https://doi.org/10.1098/rspb.2011.1439

Fang, F., Norïn, M., Liao, T. Y., Källersjö, M., \& Kullander, S. O. (2009). Molecular phylogenetic interrelationships of the south Asian cyprinid genera Danio, Devarioand Microrasbora(Teleostei, Cyprinidae, Danioninae). Zoologica Scripta, 38, 237-256.

Froese, R., \& Pauly, D. (2020). Fishbase. Retrieved from Worldwide web electronic publication, www.fishbase.org, version (01/2020) website: http://www.fishbase.org

Fujiwasa, T., \& Barraclough, T. G. (2013). Delimiting species using single-locus data and the generalized mixed yule coalescent approach: a revised mathod and evaluation on 
892 Garg, T., Hamilton, S. E., Hochard, J. P., Kresch, E. P., \& Talbot, J. (2018). (Not so) gently 893 down the stream: River pollution and health in Indonesia. Journal of Environmental Economics and Management, 92, 35-53.

895

896

897

898

899

900

901

902

903

904

905

906

907

908

909

910

911

912

913

914

915

916

Heled, J., \& Drummond, A. J. (2010). Bayesian Inference of Species Trees from Multilocus

Gaveau, D. L. A., Sloan, S., Molidena, E., Yaen, H., Sheil, D., Abram, N. K., ... Wielaard, N. (2014). Four decades of forest persistence, clearance and logging on Borneo. PloS One, $9(7)$.

Gorog, A. J., Sinaga, M. H., \& Engstrom, M. D. (2004). Vicariance or dispersal? Historical biogeography of three Sunda shelf marine rodents (Maxomys surifer, Leopoldamys sabanus and Maxomys whiteheadi). Biological Journal of the Linnean Society, 81(1), 91-109. https://doi.org/10.1111/j.1095-8312.2004.00281.x

Hall, R. (2009). Southeast Asia's changing palaeogeography. Blumea: Journal of Plant Taxonomy and Plant Geography, 54(1-3), 148-161. https://doi.org/10.3767/000651909X475941

Hall, R. (2013). The palaeogeography of Sundaland and Wallacea since the Late Jurassic. Journal of Limnology, 72(S2), 1-17. https://doi.org/10.4081/jlimnol.2013.s2.e1

Hall, R., Cottam, M. A., \& Wilson, M. E. J. (2011). The SE Asian gateway: history and tectonics of the Australia-Asia collision. Geological Society, London, Special Publications, 355(1), 1-6. https://doi.org/10.1144/SP355.1

Hardman, M., \& Lundberg, J. G. (2006). Molecular phylogeny and chronology of diversification for "phractocephaline" catfishes (Siluriformes: Pimelodidae) based on mitochondrial DNA and DNA recombination activating gene 2 sequences. Molecular Phylogenetics and Evolution, 40, 410-418.

Heaney, L. R. (1992). A synopsis of climatic and vegetational change in Southeast Asia. Tropical Forests and Climate, 53-61. https://doi.org/10.1007/978-94-017-3608-4_6 
919 Hendriks, K. P., Alciatore, G., Schilthuizen, M., \& Etienne, R. S. (2019). Phylogeography of 920 Bornean land snails suggests long distance dispersal as a cause of endemism. Journal of Biogeography.

Ho, S. Y. W., \& Larson, G. (2006). Molecular clocks: when timesare a-changin'. TRENDS in Genetics, 22(2), 79-83.

Hoffmann, M., Hilton-Taylor, C., Angulo, A., Böhm, M., Brooks, T. M., Butchart, S. H. M., 925 ... Stuart, S. N. (2010). The impact of conservation on the status of the world's vertebrates. Science, 330(6010), 1503-1509. https://doi.org/10.1126/science.1194442

927

928

929

930

931

932

933

934

935

936

937

938

939

940

941

942

943

944

Hopkins, R. L., \& Eisenhour, D. J. (2008). Hybridization of Lythrurus fasciolaris and Lythrurus umbratilis (Cypriniformes: Cyprinidae) in the Ohio River basin. Copeia, $2008(1), 162-171$.

Hubert, N., Calcagno, V., Etienne, R. S., \& Mouquet, N. (2015). Metacommunity speciation models and their implication for diversification theory. Ecology Letters, 18(8), 864-881.

Hubert, N., Calcagno, V., Etienne, R. S., \& Mouquet, N. (2015). Metacommunity speciation models and their implications for diversification theory. Ecology Letters, Vol. 18, pp. 864-881. https://doi.org/10.1111/ele.12458

Hubert, N., Duponchelle, F., Nuñez, J., Garcia-Davila, C., Paugy, D., \& Renno, J. F. (2007). Phylogeography of the piranha genera Serrasalmus and Pygocentrus: Implications for the diversification of the Neotropical ichthyofauna. Molecular Ecology, 16(10), 21152136. https://doi.org/10.1111/j.1365-294X.2007.03267.x

Hubert, N., Kadarusman, Wibowo, A., Busson, F., Caruso, D., Sulandari, S., ... Hadiaty, R. K. (2015). DNA barcoding Indonesian freshwater fishes: challenges and prospects. DNA Barcodes, 3, 144-169.

Hubert, N., Lumbantobing, D., Sholihah, A., Dahruddin, H., Delrieu-Trottin, E., Busson, F., ... Keith, P. (2019). Revisiting species boundaries and distribution ranges of Nemacheilus spp. (Cypriniformes: Nemacheilidae) and Rasbora spp. (Cypriniformes: 
945

946

947

948

949

950

951

952

953

954

955

956

957

958

959

960

961

962

963

964

965

966

967

968

969

970

971

Cyprinidae) in Java, Bali and Lombok through DNA barcodes: implications for conservation in a biodiversity hotspot. Conservation Genetics, 20(3), 517-529. https://doi.org/10.1007/s10592-019-01152-w

Hubert, N., \& Renno, J. F. (2006). Historical Biogeography of South American Freshwater fishes. Journal of Biogeography, 33, 1414-1436.

Hubert, N., Torrico, J. P., Bonhomme, F., \& Renno, J. F. (2007). Species polyphyly and mtDNA introgression among three Serrasalmus sister-species. Molecular Phylogenetics and Evolution, 46, 375-381.

Hui, T. H., \& Chian, L. K. (2020). Trigonostigma truncata, a new species of harlequin rasbora from Malay Peninsula (Teleostei: Danionidae). RAFFLES BULLETIN OF ZOOLOGY, 7600(May). https://doi.org/10.26107/RBZ-2020-0058

Husson, L., Boucher, F. C., Sarr, A. C., Sepulchre, P., \& Cahyarini, S. Y. (2020). Evidence of Sundaland's subsidence requires revisiting its biogeography. Journal of Biogeography, Vol. 47, pp. 843-853. https://doi.org/10.1111/jbi.13762

Hutama, A., Dahruddin, H., Busson, F., Sauri, S., Keith, P., Hadiaty, R. K., ... Hubert, N. (2017). Identifying spatially concordant evolutionary significant units across multiple species through DNA barcodes: Application to the conservation genetics of the freshwater fishes of Java and Bali. Global Ecology and Conservation, 12, 170-187. https://doi.org/10.1016/j.gecco.2017.11.005

Imai, N., Furukawa, T., Tsujino, R., Kitamura, S., \& Yumoto, T. (2018). Factors affecting forest area change in Southeast Asia during 1980-2010. PloS One, 13(5), e0197391.

Ivanova, N. V, Zemlak, T. S., Hanner, R. H., \& Hébert, P. D. N. (2007). Universal primers cocktails for fish DNA barcoding. Molecular Ecology Notes, 7(4), 544-548.

Iwasaki, W., Fukunaga, T., Isagozawa, R., Yamada, K., Maeda, Y., Satoh, T. P., ... Miya, M. (2013). MitoFish and MitoAnnotator: a mitochondrial genome database of fish with an accurate and automatic annotation pipeline. Molecular Biology and Evolution, 30(11), 2531-2540. 
972 Kalyaanamoorthy, S., Minh, B. Q., Wong, T. K. F., von Haeseler, A., \& Jermiin, L. S. 973 (2017). ModelFinder: fast model selection for accurate phylogenetic estimates. Nature Methods, 14(6), 587-589.

975

976

977

978

979

980

981

982

983

984

985

986

987

988

989

990

991

992

993

994

995

996

Kisel, Y., McInnes, L., Toomey, N. H., \& Orme, C. D. L. (2011). How diversification rates and diversity limits combine to create large-scale species-area relationships. Philosophical Transactions of the Royal Society B-Biological Sciences, 366(1577), 2514-2525. https://doi.org/10.1098/rstb.2011.0022

Kottelat, M. (2013). The fishes of the inland waters of Southeast Asia: a catalog and core bibliography of the fishes known to occur in freshwaters, mangroves and estuaries. The Raffles Bulletin of Zoology, Supplement, 1-663.

Kottelat, M., \& Vidthayanon, C. (1993). Boraras micros, a new genus and species of minute freshwater fish from Thailand (Teleostei: Cyprinidae). Ichthyol. Explor. Freshwaters, 4, $161-176$.

Kottelat, M., Whitten, A. J., Kartikasari, N., \& Wirjoatmodjo, S. (1993). Freshwater Fishes of Western Indonesia and Sulawesi. https://doi.org/10.2307/1447208

Kottelat, M., Whitten, A. J., Kartikasari, S. R., \& Wirjoatmodjo, S. (1993). Freshwater fishes of western indonesia and sulawesi. Singapore: Periplus editions.

Kottelat, M., \& Witte, K.-E. (1999). Two new species of Microrasbora from Thailand and Myanmar, with two new generic names for small Southeast Asian cyprinid fishes (Teleostei: Cyprinidae). Journal of South Asian Natural History, 4(1), 49-56.

Kusuma, W. E., Ratmuangkhwang, S., \& Kumazawa, Y. (2016). Molecular phylogeny and historical biogeography of the Indonesian freshwater fish Rasbora lateristriata species complex (Actinopterygii: Cyprinidae): Cryptic species and west-to-east divergences. Molecular Phylogenetics and Evolution, 105, 212-223. https://doi.org/10.1016/j.ympev.2016.08.014

997 Laumonier, Y., Uryu, Y., Stüwe, M., Budiman, A., Setiabudi, B., \& Hadian, O. (2010). Eco998 floristic sectors and deforestation threats in Sumatra: identifying new conservation area network priorities for ecosystem-based land use planning. Biodiversity and 
1001 Liao, T. Y., Kullander, S. O., \& Fang, F. (2010). Phylogenetic analysis of the genus Rasbora 1002 (Teleostei: Cyprinidae). Zoologica Scripta, 39(2), 155-176.

1003 Liao, T. Y., Kullander, S. O., \& Fang, F. (2011). Phylogenetic position of rasborin cyprinids

1004

1005

1006

1007

1008

1009

1010

1011

1012

1013

1014

1015

1016

1017

1018

1019

1020

1021

1022

1023

1024

1025

1026 and monophyly of major lineages among the Danioninae, based on morphological characters (Cypriniformes: Cyprinidae). Journal of Zoological Systematics and Evolutionary Research, 49(3), 224-232. https://doi.org/10.1111/j.14390469.2011.00621.x

Lim, N. K. M., Tay, Y. C., Srivathsan, A., Tan, J. W. T., Kwik, J. T. B., Baloğlu, B., ... Yeo, D. C. J. (2016). Next-generation freshwater bioassessment: eDNA metabarcoding with a conserved metazoan primer reveals species-rich and reservoir-specific communities. Royal Society Open Science, 3(11), 160635.

Logue, J. B., Mouquet, N., Hannes, P., Hillebrand, H., \& group, T. metacommunity working. (2011). Empirical approaches to metacommunities: a review and comparison with theory. Trends in Ecology and Evolition, 26(9), 482-491.

Lohman, K., De Bruyn, M., Page, T., Von Rintelen, K., Hall, R., Ng, P. K. L., ... Von Rintelen, T. (2011). Biogeography of the Indo-Australian archipelago. Annual Review of Ecology, Evolution and Systematics, 42, 205-226.

Lumbantobing, D. N. (2010). Analisis filogenetik genus Rasbora (Teleostei: Cyprinidae) berdasarkan karakter morfologis. Jurnal Iktiollogi Indonesia, 10(2), 185-189.

Matzke, N. J. (2013). Probabilistic historical biogeography: new models for founder-event speciation, imperfect detection, and fossils allow improved accuracy and model-testing. Frontiers of Biogeography, 5(4), 242-248. https://doi.org/10.21425/f55419694

Matzke, N. J. (2014). Model selection in historical biogeography reveals that founder-event speciation is a crucial process in island clades. Systematic Biology, 63(6), 951-970. https://doi.org/10.1093/sysbio/syu056

Mayden, R. L., Tang, K. L., Conway, K. W., Freyhof, J., Chamberlain, S., Haskins, M., ... 
1035

1036

1037

1038

1039

1040

1041

1042

1043

1044

1045

1046

1047

1048

1049

1050

1051

1052

He, S. (2007). Phylogenetic relationships of Danio within the order Cypriniformes: a framework for comparative and evolutionary studies of a model species. Journal of Experimental Zoology, 308B, 642-654.

Meyer, M., \& Kircher, M. (2010). Illumina sequencing library preparation for highly multiplexed target capture and sequencing. Cold Spring Harbor Protocols, 2010(6), pdb-prot5448.

Miller, K. G., Kominz, M. A., Browning, J. V, Wright, J. D., Mountain, G. S., Katz, M. E., ... Pekar, S. F. (2005). The phanerozoic record of global sea-level change. Science, Vol. 310, pp. 1293-1298. https://doi.org/10.1126/science.1116412

Miller, M. A., Pfeiffer, W., \& Schwartz, T. (2010). Creating the CIPRES Science Gateway for inference of large phylogenetic trees. 2010 Gateway Computing Environments Workshop, GCE 2010. https://doi.org/10.1109/GCE.2010.5676129

Mittelbach, G. G., Schemske, D. W., Cornell, H. V, Allen, A. P., Brown, J. M., Bush, M. B., ... Turelli, M. (2007). Evolution and the latitudinal diversity gradient: speciation, extinction and biogeography. Ecology Letters, 10, 315-331.

Mittermeier, R. A., Turner, W. R., Larsen, F. W., Brooks, T. M., \& Gascon, C. (2011). Global biodiversity conservation: the critical role of hotspots. In Biodiversity hotspots (pp. 3-22). Springer.

Morlon, H., Lewitus, E., Condamine, F. L., Manceau, M., Clavel, J., \& Drury, J. (2016). RPANDA: an $\mathrm{R}$ package for macroevolutionary analyses on phylogenetic trees. Methods in Ecology and Evolution, 7(5), 589-597.

Mulligan, M., van Soesbergen, A., \& Sáenz, L. (2020). GOODD, a global dataset of more than 38,000 georeferenced dams. Scientific Data, 7(1), 1-8.

Myers, N., Mittermeier, R. A., Mittermeier, C. G., da Fonseca, G. A. B., \& Kent, F. (2000). Biodiversity hotspots for conservation priorities. Nature, 403, 853-858.

Nguyen, L.-T., Schmidt, H. A., Von Haeseler, A., \& Minh, B. Q. (2015). IQ-TREE: a fast and effective stochastic algorithm for estimating maximum-likelihood phylogenies. 
1055

1056

1057

1058

1059

1060

1061

1062

1063

1064

1065

1066

1067

1068

1069

1070

1071

1072

1073

1074

1075

1076

1077

1078

1079

1080

1081

Nguyen, T. T. T., Na-Nakorn, U., Sukmanomon, S., \& ZiMing, C. (2008). A study on phylogeny and biogeography of mahseer species (Pisces: Cyprinidae) using sequences of three mitochondrial DNA gene regions. Molecular Phylogenetics and Evolution. https://doi.org/10.1016/j.ympev.2008.01.006

Nores, M. (1999). An alternative hypothesis for the origin of Amazonian bird diversity. Journal of Biogeography, 26(3), 475-485. https://doi.org/10.1046/j.13652699.1999.t01-1-00311.x

Nurul Farhana, S., Muchlisin, Z. A., Duong, T. Y., Tanyaros, S., Page, L. M., Zhao, Y., ... Siti Azizah, M. N. (2018). Exploring hidden diversity in Southeast Asia's Dermogenys spp. (Beloniformes: Zenarchopteridae) through DNA barcoding. Scientific Reports, 8(1), 10787. https://doi.org/10.1038/s41598-018-29049-7

Ogilvie, H. A., Bouckaert, R. R., \& Drummond, A. J. (2017). StarBEAST2 brings faster species tree inference and accurate estimates of substitution rates. Molecular Biology and Evolution, 34(8), 2101-2114. https://doi.org/10.1093/molbev/msx126

Okonechnikov, K., Golosova, O., Fursov, M., Varlamov, A., Vaskin, Y., Efremov, I., ... Tleukenov, T. (2012). Unipro UGENE: A unified bioinformatics toolkit. Bioinformatics, 28(8), 1166-1167. https://doi.org/10.1093/bioinformatics/bts091

Orti, G. (1997). Radiation of Characiforms Fishes: Evidence from Mitochondrial and Nuclear DNA sequences. In Molecular Systematics of Fishes. Academic Press.

Papadopoulou, A., \& Knowles, L. L. (2015a). Genomic tests of the species-pump hypothesis: Recent island connectivity cycles drive population divergence but not speciation in Caribbean crickets across the Virgin Islands. Evolution, 69(6), 1501-1517. https://doi.org/10.1111/evo.12667

Papadopoulou, A., \& Knowles, L. L. (2015b). Species-specific responses to island connectivity cycles: Refined models for testing phylogeographic concordance across a Mediterranean Pleistocene Aggregate Island Complex. Molecular Ecology, 24(16), 4252-4268. https://doi.org/10.1111/mec. 13305 
1082

1083

1084

1085

1086

1087

1088

1089

1090

1091

1092

1093

1094

1095

1096

1097

1098

1099

1100

1101

1102

1103

1104

1105

1106

1107

1108

Paradis, E., \& Schliep, K. (2019). ape 5.0: an environment for modern phylogenetics and evolutionary analyses in R. Bioinformatics, 35(3), 526-528.

Patel, S., Weckstein, J. D., Patane, J. S., Bates, J. M., \& Aleixo, A. (2011). Temporal and spatial diversification of Pteroglossus aracaris (AVES: Ramphastidae) in the neotropics: constant rate of diversification does not support an increase in radiation during the Pleistocene. Mol Phylogenet Evol, 58(1), 105-115. https://doi.org/10.1016/j.ympev.2010.10.016

Phillimore, A. B., \& Price, T. D. (2008). Density-dependent cladogenesis in birds. PLoS Biology, 6(3), e71. https://doi.org/10.1371/journal.pbio.0060071

Pouyaud, L., Sudarto, \& Paradis, E. (2009). The phylogenetic structure of habitat shift and morphological convergence in Asian Clarias (Teleostei, Siluriformes: Clariidae). Journal of Zoological Systematics and Evolutionary Research, 47(4), 344-356. https://doi.org/10.1111/j.1439-0469.2008.00507.x

Puillandre, N., Lambert, A., Brouillet, S., \& Achaz, G. (2012). ABGD, Automatic Barcode Gap Discovery for primary species delimitation. Molecular Ecology, 21, 1864-1877.

Rabosky, D. L., Chang, J., Title, P. O., Cowman, P. F., Sallan, L., Friedman, M., ... Coll, M. (2018). An inverse latitudinal gradient in speciation rate for marine fishes. Nature, $559(7714), 392$.

Ratnasingham, S., \& Hebert, P. D. N. (2007). BOLD: The Barcode of Life Data System (www.barcodinglife.org). Molecular Ecology Notes, 7(3), 355-364. https://doi.org/DOI $10.1111 / \mathrm{j} .1471-8286.2006 .01678 . x$

Ratnasingham, S., \& Hebert, P. D. N. (2013). A DNA-Based Registry for All Animal Species: The Barcode Index Number (BIN) System. PLoS ONE, 8(7). https://doi.org/10.1371/journal.pone.0066213

Ree, R. H., \& Sanmartín, I. (2018). Conceptual and statistical problems with the DEC+ J model of founder event speciation and its comparison with DEC via model selection. Journal of Biogeography, 45(4), 741-749. 
1109

1110

1111

1112

1113

1114

1115

1116

1117

1118

1119

1120

1121

1122

1123

1124

1125

1126

1127

1128

1129

1130

1131

1132

1133

1134

1135

1136

Ríos, N., Bouza, C., \& García, G. (2019). Past hybridisation and introgression erased traces of mitochondrial lineages evolution in the Neotropical silver catfish Rhamdia quelen (Siluriformes: Heptapteridae). Hydrobiologia, 830(1), 161-177.

Ritchie, A. M., Lo, N., \& Ho, S. Y. W. (2017). The impact of the tree prior on molecular dating of data sets containing a mixture of inter-and intraspecies sampling. Systematic Biology, 66(3), 413-425.

Rüber, L., Kottelat, M., Tan, H., Ng, P., \& Britz, R. (2007). Evolution of miniaturization and the phylogenetic position of Paedocypris, comprising the world's smallest vertebrate. BMC Evolutionary Biology, 7(38).

Saitoh, K., Sado, T., Mayden, R., Hanzawa, N., Nakamura, K., Nishida, M., \& Miya, M. (2006). Mitogenomic evolution and interrelationships of the cypriniformes (Actinopterygii: Ostariophysi): the first evidence toward resolution of higher level relationships of the world's largest freshwater fish clade based on 59 whole mitogenome sequences. Journal of Molecular Evolution, 63, 826-841.

Sarr, A., Sepulchre, P., \& Husson, L. (2019). Impact of the Sunda Shelf on the Climate of the Maritime Continent. Journal of Geophysical Research: Atmospheres, 124(5), 25742588.

Sathiamurthy, E., \& Voris, K. H. (2006). Maps of Holocene Sea Level Transgression and Submerged Lakes on the Sunda Shelf. In The Natural History Journal of Chulalongkorn University, Supplement (Vol. 2).

Sholihah, A., Delrieu-Trottin, E., Condamine, F. L., Wowor, D., Rüber, L., Pouyaud, L., ... Hubert, N. (2021). Impact of Pleistocene Eustatic Fluctuations on Evolutionary Dynamics in Southeast Asian Biodiversity Hotspots. Systematic Biology.

Sholihah, A., Delrieu-Trottin, E., Sukmono, T., Dahruddin, H., Risdawati, R., Elvyra, R., ... Hubert, N. (2020). Disentangling the taxonomy of the subfamily Rasborinae (Cypriniformes, Danionidae) in Sundaland using DNA barcodes. Scientific Reports.

Šlechtová, V., Musilova, Z., Hui Tan, H., Kottelat, M., \& Bohlen, J. (2021). One northward, one southward: contrasting biogeographical history in two benthic freshwater fish 

genera across Southeast Asia (Teleostei: Cobitoidea: Nemacheilus, Pangio). Molecular Phylogenetics and Evolution,

107139. https://doi.org/https://doi.org/10.1016/j.ympev.2021.107139

Stamatakis, A. (2014). RAxML version 8: a tool for phylogenetic analysis and post-analysis of large phylogenies. Bioinformatics, 30(9), 1312-1313.

Stout, C. C., Tan, M., Lemmon, A. R., Lemmon, E. M., \& Armbruster, J. W. (2016). Resolving Cypriniformes relationships using an anchored enrichment approach. BMC Evolutionary Biology, 16(1), 244.

Straub, S. C. K., Parks, M., Weitemier, K., Fishbein, M., Cronn, R. C., \& Liston, A. (2012). Navigating the tip of the genomic iceberg: Next generation sequencing for plant systematics. American Journal of Botany, 99(2), 349-364.

Swofford, D. L. (2001). Version 4.0 b10. PAUP ${ }^{\wedge *}$. Phylogenetic Analysis Using Parsimony (^* and Other Methods).

Tan, H. H., \& Lim, K. K. P. (2013). Three new species of freshwater halfbeaks (Teleostei: Zenarchopteridae: Hemirhamphodon) from Borneo. Raffles Bulletin of Zoology, 61(2), $735-747$.

Tan, M., \& Armbruster, J. W. (2018). Phylogenetic classification of extant genera of fishes of the order Cypriniformes (Teleostei: Ostariophysi). Zootaxa, 4476(1), 6-39.

Tan, M. P., Jamsari, A. F. J., \& Siti Azizah, M. N. (2012). Phylogeographic pattern of the striped snakehead, channa striata in Sundaland: ancient river connectivity, geographical and anthropogenic signatures. PLoSONE, 7(12), e52089.

Tang, K. L., Agnew, M. K., Hirt, M. V., Sado, T., Schneider, L. M., Freyhof, J., ... Mayden, R. L. (2010). Systematics of the subfamily Danioninae (Teleostei: Cypriniformes: Cyprinidae). Molecular Phylogenetics and Evolution, 57(1), 189-214. https://doi.org/10.1016/j.ympev.2010.05.021 incomplete lineage sorting in the diversification of balitorine loaches (Cypriniformes, 
Balitoridae) revealed by mitochondrial and nuclear genes. Zoologica Scripta, 41(3), 233-247.

1166

1167

1168

1169

1170 1171

1172

1173 1174

1175

1176

1177 1178

1179

1180

1181

1182

1183

1184

1185

1186 1187

1188

1189

1190

Tilak, M.-K., Justy, F., Debiais-Thibaud, M., Botero-Castro, F., Delsuc, F., \& Douzery, E. J. P. (2015). A cost-effective straightforward protocol for shotgun Illumina libraries designed to assemble complete mitogenomes from non-model species. Conservation Genetics Resources, 7(1), 37-40.

Van Dam, M. H., \& Matzke, N. J. (2016). Evaluating the influence of connectivity and distance on biogeographical patterns in the south-western deserts of North America. Journal of Biogeography, 43(8), 1514-1532. https://doi.org/10.1111/jbi.12727

Voris, H. K. (2000). Maps of Pleistocene sea levels in Southeast Asia: Shorelines, river systems and time durations. Journal of Biogeography, 27(5), 1153-1167. https://doi.org/10.1046/j.1365-2699.2000.00489.x

Wallace, A. R. (1869). The Malay Archipelago. London: Harper.

Wallis, G. P., Cameron Christie, S. R., Kennedy, H. L., Palmer, G., Sanders, T. R., \& Winter, D. J. (2017). Interspecific hybridization causes long term phylogenetic discordance between nuclear and mitochondrial genomes in freshwater fishes. Molecular Ecology, 26(12), 3116-3127.

Weir, J. T., \& Schluter, D. (2007). The latitudinal gradient in recent speciation and extinction rates of birds and mammals. Science, 315, 1574-1576.

Westerhold, T., Marwan, N., Drury, A. J., Liebrand, D., Agnini, C., Anagnostou, E., ... Florindo, F. (2020). An astronomically dated record of Earth's climate and its predictability over the last 66 million years. Science, 369(6509), 1383-1387.

Wiens, J. J., \& Donoghue, M. J. (2004). Historical biogeography, ecology and species richness. Trends in Ecology and Evolution, 19(12), 639-644.

Woodruff, D. S. (2010). Biogeography and conservation in Southeast Asia: How 2.7 million years of repeated environmental fluctuations affect today's patterns and the future of the remaining refugial-phase biodiversity. Biodiversity and Conservation, 19(4), 919-941. 
1192 Wurster, C. M., Rifai, H., Zhou, B., Haig, J., \& Bird, M. I. (2019). Savanna in equatorial 1193 Borneo during the late Pleistocene. Scientific Reports, 9(1), 1-7. 1194 https://doi.org/10.1038/s41598-019-42670-4

1195 Zachos, J. C., Dickens, G. R., \& Zeebe, R. E. (2008). An early Cenozoic perspective on 1196 greenhouse warming and carbon-cycle dynamics. Nature, 451(7176), 279-283.

1197 Zhang, J., Kapli, P., Pavlidis, P., \& Stamatakis, A. (2013). A general species delimitation 1198 method with applications to phylogenetic placements. Bioinformatics, 29(22), 28691199 2876. https://doi.org/10.1093/bioinformatics/btt499

1200 
1201

1202

1203

1204

1205

1206

1207

1208

1209

1210

1211

1212

1213

1214

1215

1216

\section{Biosketch}

Arni Sholihah is a lecturer at Institut Teknologi Bandung (Indonesia), and obtained her $\mathrm{PhD}$ at the doctoral school GAIA (Université de Montpellier). She is interested in the biogeography and conservation of Southeast Asian biotas. The team consists in evolutionary biologists and/or specialists of Southeast Asian freshwater biotas interested in mechanisms of diversity build-up and conservation.

\section{Editor: Jonathan Waters}

Author contributions: AS, DW, LR and NH conceived the study. AS, TS, HD, DW, LR and NH conducted sampling. AS, EDT, JP, MKT, YF, JFA, LR and NH conducted the sequencing. AS, EDT, FC, LR and $\mathrm{NH}$ analysed the data. AS and $\mathrm{NH}$ drafted the initial version of the manuscript, and all authors further contributed to draft and approved the final version.

\section{Appendices}

1217 Figure S1 Bayesian maximum clade credibility tree of Rasborinae based on 14 partitions (13 1218 protein coding and one rRNA coding partitions), two prior clock rates $(0.3 \%$ per Myrs for 1219 rRNA partition, $1.2 \%$ per Myrs for the 13 protein coding partitions) and a birth-death 1220 diversification model. Node circles indicate posterior probabilities (PP) and node bars 1221 represent $95 \%$ highest posterior density (HPD) of age estimates.

Figure S2 Lineage through time plots for each clade and distribution of the species and MOTUs age estimates (A), speciation rates through time according to BCST model for each clade (B), sea-levels (C, following Miller et al. 2005).

1226

Figure S3 Geographic pattern of speciation in Rasborinae. The plots show the numbers of 1228 speciation events associated to the four geographic patterns of speciation as follows: between islands and within paleorivers, between islands and between paleorivers, within islands and within paleorivers, and within islands and between paleorivers. Each bar shows the number of speciation events for each category for all clades (A), Clade I (B), Clade II (C), Clade III 1232 (D), and Clade IV (E). 
1234 Figure S4 Mitochondrial MOTU trees reconstructed using StarBEAST2. A to D, Bayesian 1235 maximum credibility species trees for Clades I, II, III and IV, respectively, including 1236 posterior probabilities (PP, node circles) and 95\% highest posterior density (HPD, node bars). 1237

1238 Table S1 List of DNA sequences used in present study, including systematic (Order, family, 1239 genus, species and updated species names), field numbers (BOLD), GenBank accession 1240 numbers for COI and Complete Mitochondrial Genomes (CMG), OTU numbers assigned, 1241 locality, geographic distribution (Locality, island and paleoriver) and phylogenetic status 1242 (ingroup, outgroup).

1243

1244 Table S2 Description of the 17 diversification models tested including acronym, rate 1245 variation, number of parameters and parameters involved (see material and methods section 1246 for details).

1247

1248 Table S3 Likelihood scores for each diversification model for each group. Description of 1249 each model can be found in Table S1.

1250

1251 Table S4 Log likelihood scores and Akaike Information Criterion values for DEC, DEC $+\mathrm{J}$, $1252 \mathrm{DIV}, \mathrm{DIV}+\mathrm{J}, \mathrm{BAY}$ and $\mathrm{BAY}+\mathrm{J}$ as calculated using BioGeoBEARS for island-based and 1253 paleoriver-based partitioning.

1254

\section{Figures and Tables captions}

1256 Figure 1 Geological reconstructions of the Indo-Australian archipelago since the middle 1257 Oligocene (modified from Lohman et al. 2011), paleoriver reconstruction in the Pleistocene 1258 (modified from Voris, 2000 and Woodruff, 2010) and sea levels fluctuations (adapted from 1259 Miller et al. 2005). A, middle Oligocene ca. 30 Ma. B, early Miocene ca. 20 Ma. C, late 1260 Miocene ca. 10 Ma. D, early Pliocene ca. 5 Ma. E, modern including limits of exposed land 1261 during $-60 \mathrm{~m}$ and $-120 \mathrm{~m}$ sea level drops, contour of the paleoriver watersheds and sampling 1262 sites. F, sea level reconstructions over the last 15 Myr.

1264 Figure 2 Mechanisms of lineage dispersal and proliferation through eustasy (Paleoriver 1265 hypothesis). During interglacial times, sea-level highstands induce a fragmentation of 1266 watersheds into multiple tributaries further connected during sea-level lowstands of glacial 1267 times. In situ radiation panel depicts a scenario of watershed colonisation during glacial times 
1268

1269

1270

1271

1272

1273

1274

1275

1276

1277

1278

1279

1280

1281

1282

1283

1284

1285

1286

1287

1288

1289

1290

1291

1292

1293

1294

1295

1296

1297

1298

1299 Figure 5 Mitochondrial ancestral area estimations of Rasborinae Clades I, II, III, and IV. A 1300

from an initial ancestor (a), further fragmented during sea-level highstand and resulting in a locally radiating lineage (a1-a8). Jump dispersal and in situ radiation panel depicts a scenario of watershed colonisation during glacial times from two ancestors $(a, b)$, further fragmented during sea-level highstands and resulting in multiple local radiations (b1-b2, a1-a6).

Figure 3 Phylogenetic reconstructions in Rasborinae based on 79 mitogenomes with Rasborinae taxa in black, outgroups in grey and four major clades labelled Clade I to Clade IV. A, Bayesian maximum clade credibility tree based on 14 partitions (13 protein coding and one rRNA coding partitions), two prior clock rates (0.3\% per Myrs for rRNA partition, $1.2 \%$ per Myrs for the 13 protein coding partitions) and a Yule diversification model. Node circles indicate posterior probabilities (PP) and node bars represent 95\% highest posterior density (HPD) of age estimates. B, Maximum likelihood phylogenetic tree based on 14 partitions (13 protein coding and one rRNA coding partitions). Node circles indicate bootstrap proportion (BP).

Figure 4 Mitochondrial gene trees of Rasborinae Clades I, II, III and IV. Maximum likelihood trees and bootstrap proportions (BP, node circles) are in panels A, C, E, and G, or Clades I, II, III and IV, respectively. Bayesian maximum clade credibility trees, posterior probabilities (PP, node circles) and 95\% highest posterior density (HPD, node bars) are in panels B, D, F, and H for Clades I, II, III, and IV, respectively. All ML trees were rooted using A. mola, $R$. vaterifloris and H. atukorali, Clade I ML tree (A) included additional extragroups as follows: $R$. cephalotaenia, $R$. einthovenii, $R$. sumatrana, $R$. dusonensis, $R$. aprotaenia, $R$. semilineata, $R$. rutteni, $R$. bankanensis, and $R$. borneensis. Clade II ML tree (C) included additional extra-groups as follows: $R$. cephalotaenia, $R$. einthovenii, $R$. sumatrana, $R$. dusonensis, $R$. aprotaenia, B. maculatus, $T$. n sp, and P. balaena. Clade III ML tree (E) included additional extra-groups as follows: B. maculatus, T. $\mathrm{n} \mathrm{sp,} \mathrm{P.} \mathrm{balaena,} R$. borneensis, $R$. bankanensis, $R$. semilineata, R. rutteni, $R$. sumatrana, $R$. dusonensis, and $R$. aprotaenia. Clade IV ML tree (G) included additional extra-groups as follows: B. maculatus, $T$. $\mathrm{n}$ sp, P. balaena, $R$. borneensis, $R$. bankanensis, $R$. semilineata, $R$. rutteni, $R$. cephalotaenia, and R. einthovenii. to D, ancestral area estimations for Clades I, II, III, and IV, respectively, according to an 
1301 island-based (left) or paleoriver-based (right) geographical partitioning. Nodes labelling is 1302 temporally ordered and referred in the text.

1303

1304 Figure 6 Dispersal pathways and in situ diversification among Sundaland Rasborinae 1305 between 31-17.5 Ma (A, Early Miocene), 17.5-7.5 Ma (B, Late Miocene) and 7.5 Ma-present 1306 (C, Early Pliocene). Arrows represent dispersal pathways according to ancestral area 1307 estimations (Table 2) and stars indicates in situ diversification.

1308

1309 Table 1 Summary statistics of the most likely diversification models for Rasborinae Clades I, 1310 II, III, and IV including acronym, rate variation, number of parameters (NP), speciation rates $1311(\lambda)$, corrected Akaike Information Criterion (AICc) and Akaike weight (AIC $\omega$ ).

1312

1313 Table 2 Freshwater dispersal pathways and associated clades through time.

1314

1315 Table 3 Summary statistics of geographical patterns of lineage divergence for Rasborinae 1316 Clades I, II, III, and IV. 

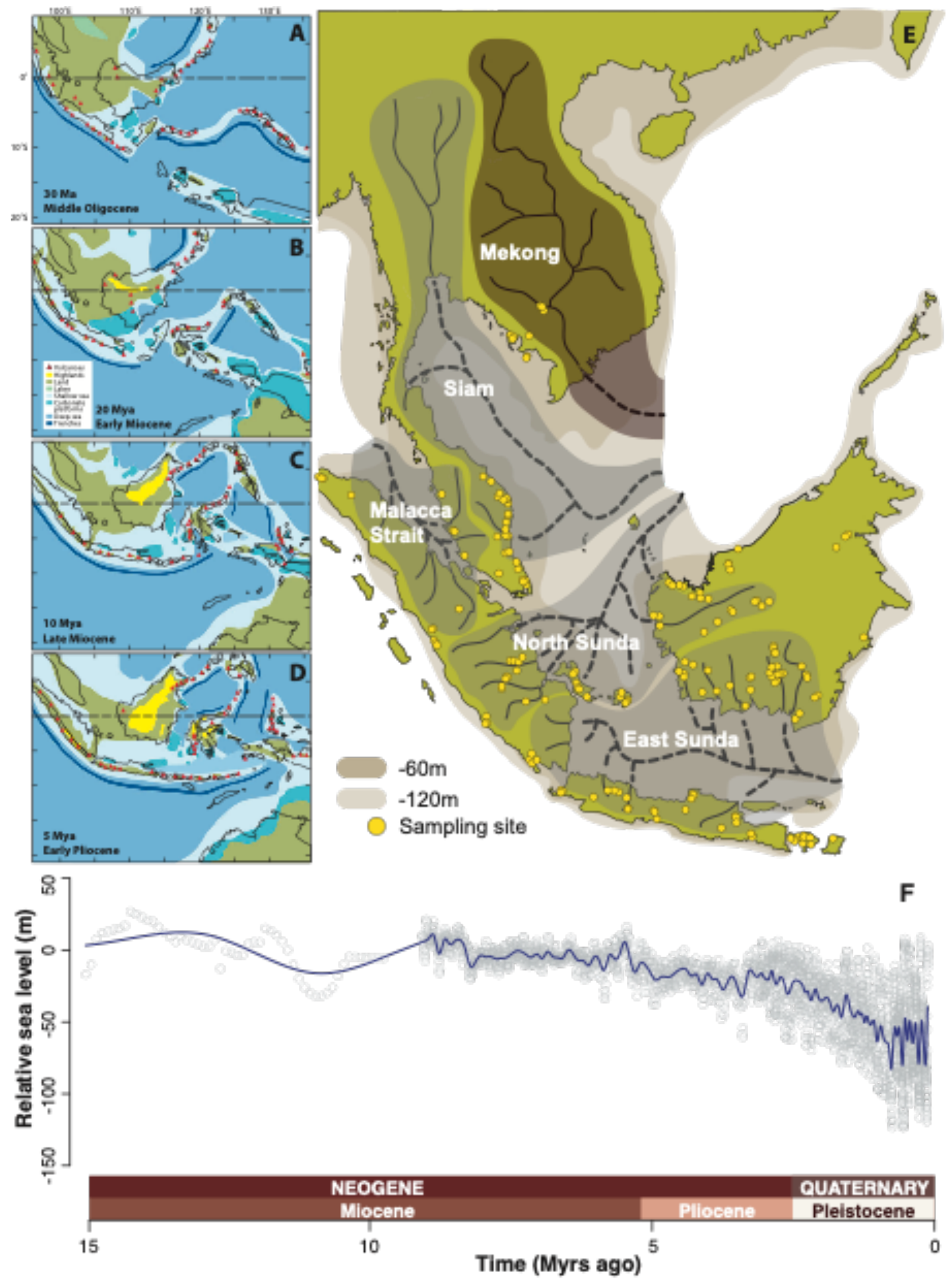

Fig. 1 


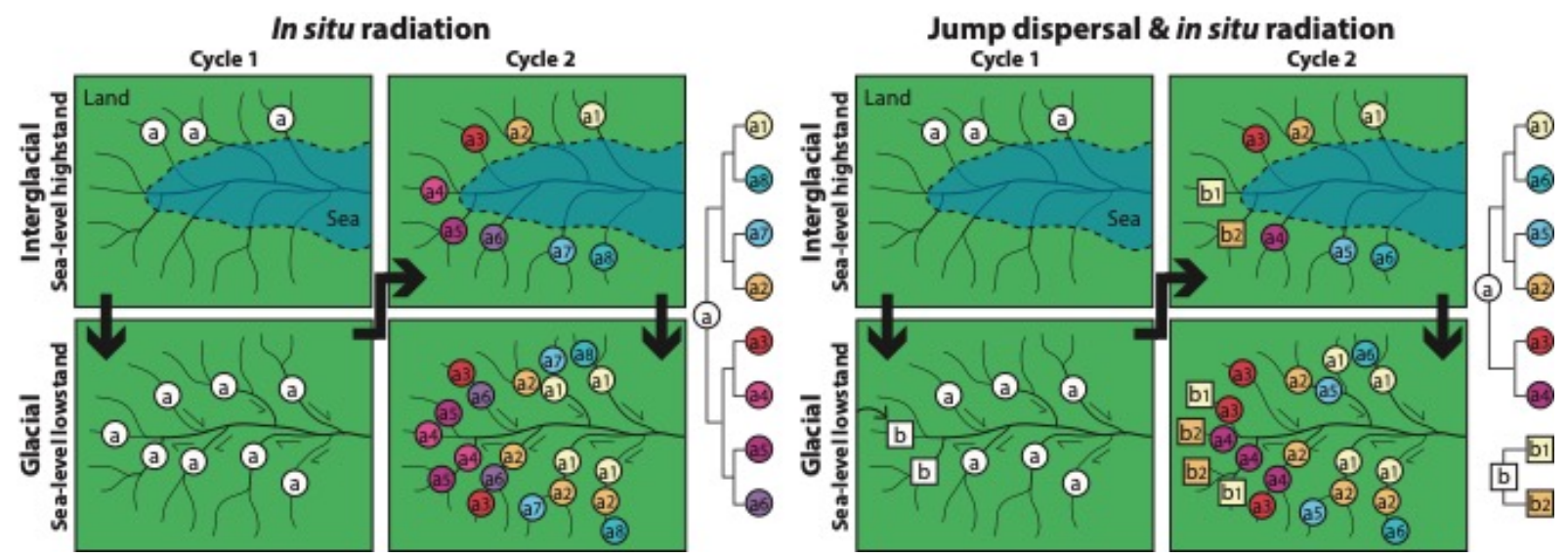

Fig. 2 


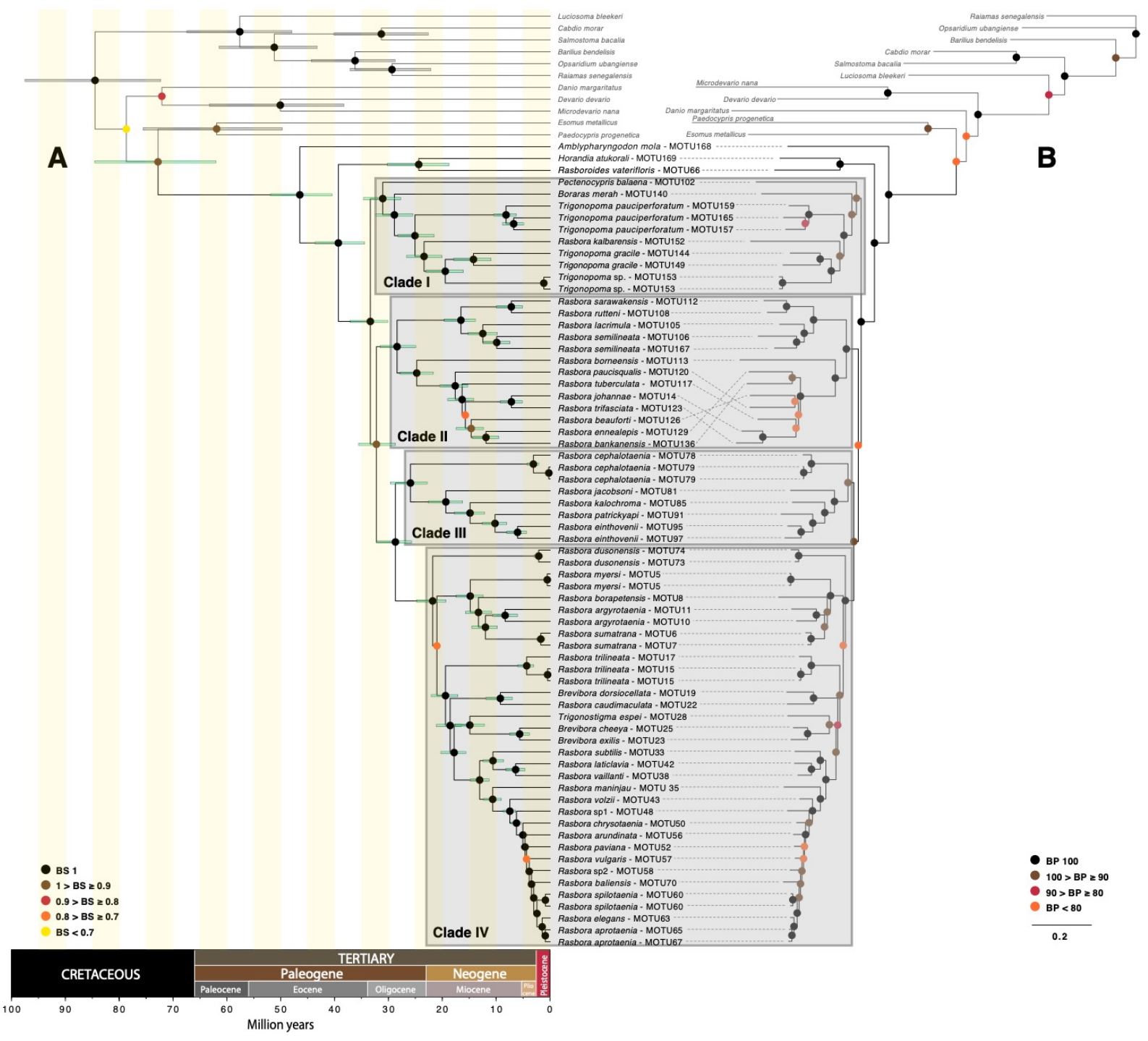

Fig. 3 


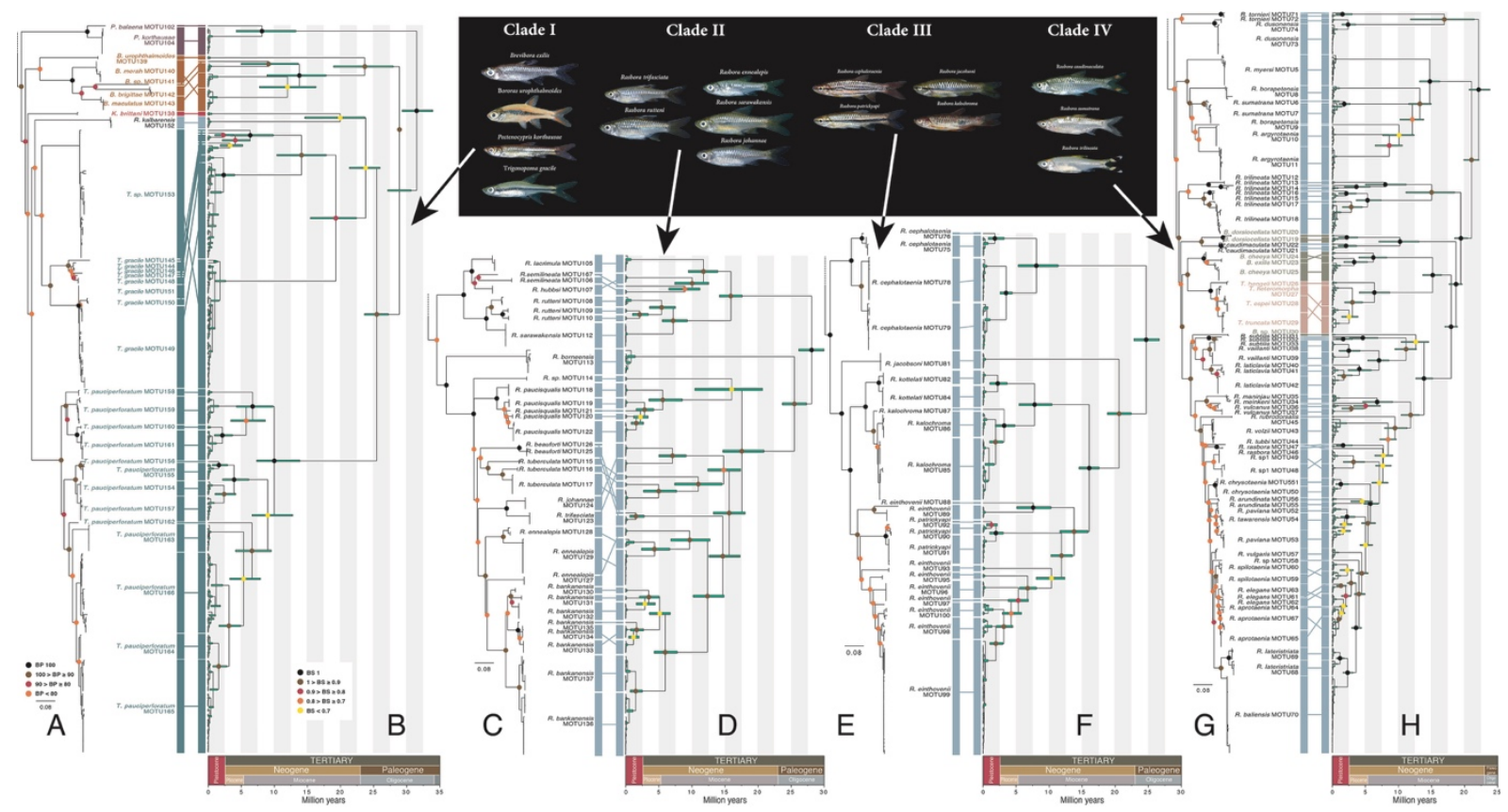

Fig. 4 


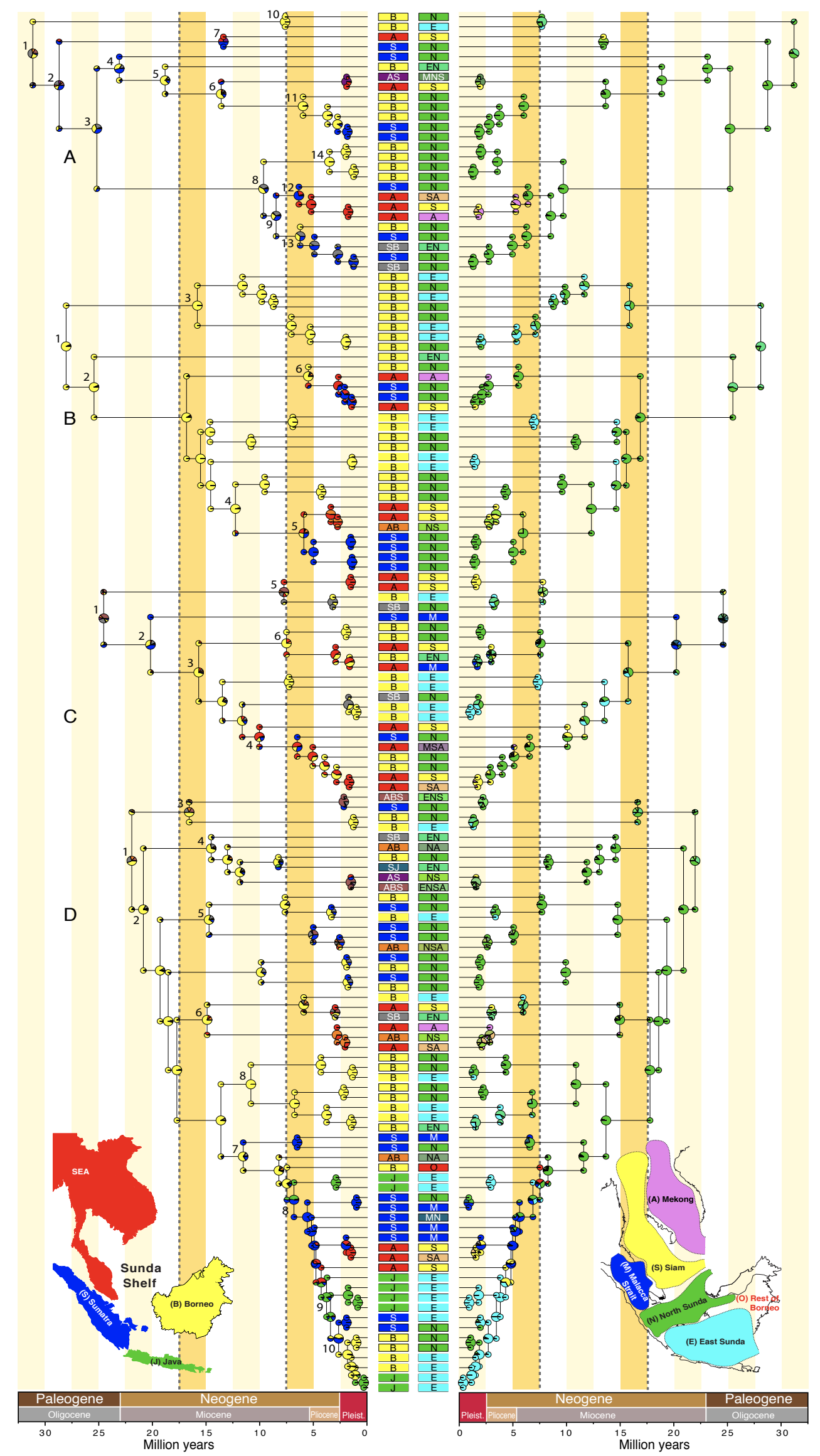

Fig. 5 

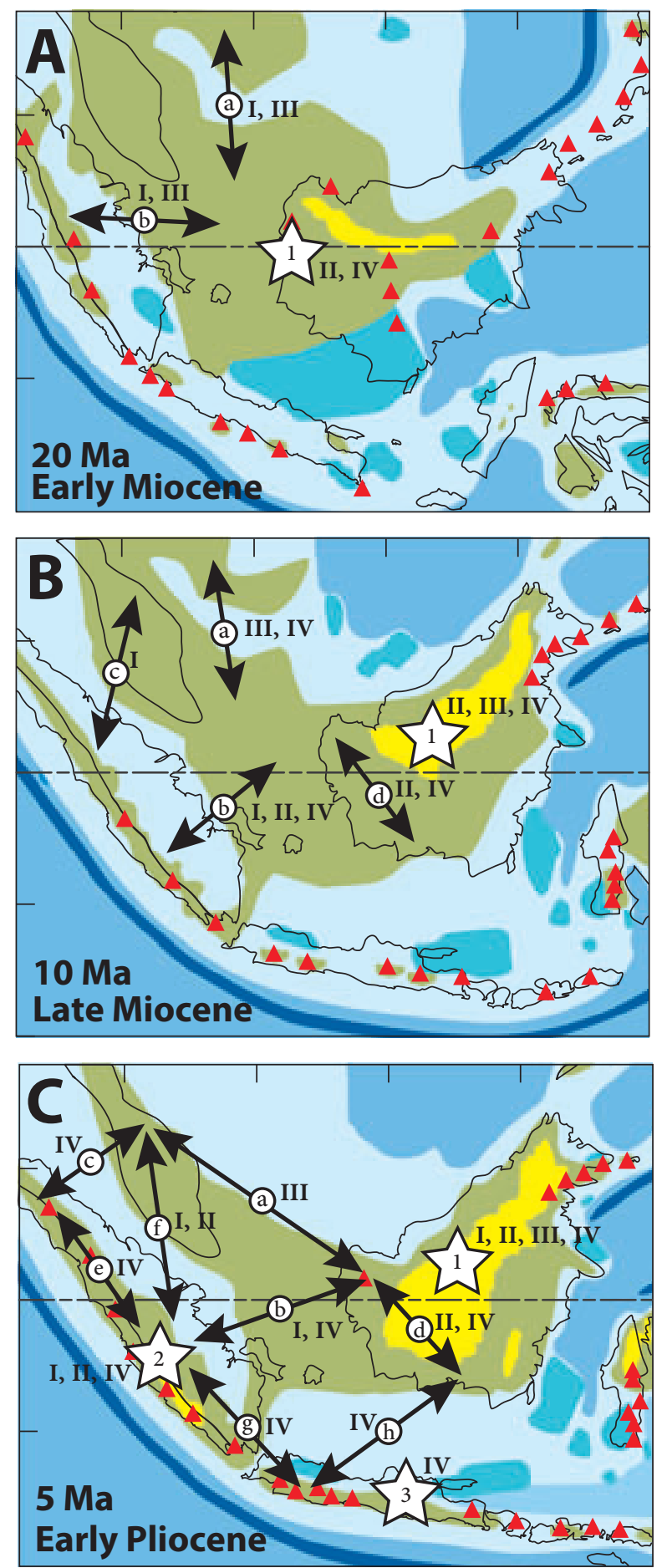

Fig. 6 